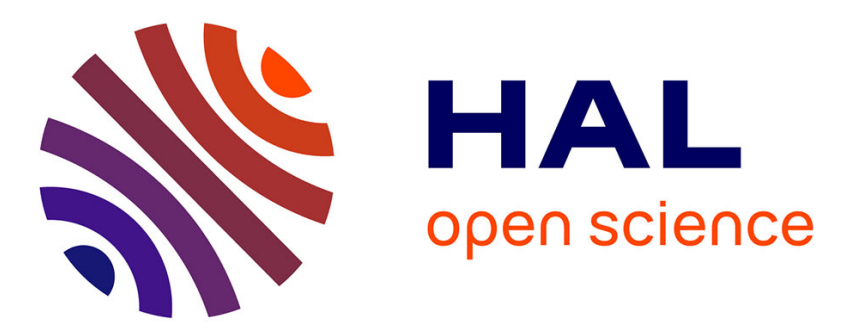

\title{
The pace of grammaticalization and the evolution of prepositional systems: Data from Romance
}

\author{
Benjamin Fagard, Alexandru Mardale
}

\section{To cite this version:}

Benjamin Fagard, Alexandru Mardale. The pace of grammaticalization and the evolution of prepositional systems: Data from Romance. Folia Linguistica, 2012, 46 (2), pp.303-340. halshs-01241407

\section{HAL Id: halshs-01241407 https://shs.hal.science/halshs-01241407}

Submitted on 10 Dec 2015

HAL is a multi-disciplinary open access archive for the deposit and dissemination of scientific research documents, whether they are published or not. The documents may come from teaching and research institutions in France or abroad, or from public or private research centers.
L'archive ouverte pluridisciplinaire HAL, est destinée au dépôt et à la diffusion de documents scientifiques de niveau recherche, publiés ou non, émanant des établissements d'enseignement et de recherche français ou étrangers, des laboratoires publics ou privés. 


\section{The pace of grammaticalization and the evolution of prepositional systems: Data from Romance}

It is generally assumed that grammaticalization is a major process in linguistic change (Lehmann 1985, Marchello-Nizia 2006). It is also assumed that grammaticalization does not affect homogeneously all linguistic categories (Hopper \& Traugott 2003), or even all languages: it has been said, for instance, that some languages are further down most grammaticalization clines than others and, thus, appear more grammaticalized than others (see, for French, Lamiroy 1999, 2001, 2003, 2011, Carlier 2007, De Mulder 2001, De Mulder \& Lamiroy to appear; for English, König \& Gast 2007). In this paper, we illustrate the uneven pace of grammaticalization in Romance by analysing a specific area of language, viz. simple and complex prepositions. Our goal is to establish a list of prepositions which are in actual use in five present-day Romance languages (to wit, French, Italian, Portuguese, Romanian and Spanish). In order to do so, we check the validity of existing lists against written and spoken corpora, and evaluate the degree of grammaticalization of each morpheme or construction, on the basis of (mainly) morpho-syntactic criteria. Additionally, and most importantly, a corpusbased approach makes it possible to observe these items' frequency (Bybee 2006). The result offers a clear picture of the degree of grammaticalization of prepositions in present-day Romance, showing that French seems indeed to be the most grammaticalized Romance language, followed by Italian, Spanish, Portuguese and Romanian.

Keywords: adpositions, Romance, diachrony, corpus, grammaticalization.

Benjamin Fagard

Lattice (CNRS - ENS)

1 rue Maurice Arnoux

92120 Montrouge

France

benjamin.fagard@ens.fr

Alexandru Mardale

INALCO, ECO - Section de roumain \& SeDyL, UMR 8202 CNRS

65, rue des Grands Moulins

75013 Paris

France

alexandru.mardale@inalco.fr 


\section{Introduction}

The study of linguistic evolution has changed much in the last twenty years or so, partly thanks to extensive research on grammaticalization. This phenomenon seems to play a major role in language change (Lehmann 1985, Marchello-Nizia 2006): grammatical elements are overwhelmingly the result of grammaticalization, in all natural languages. ${ }^{1}$

It has been assumed, however, that grammaticalization does not affect homogeneously all linguistic categories (Hopper \& Traugott 2003). It has even been said that, though grammaticalization seems to affect languages universally, it may do so in different ways. More specifically, the speed with which constructions undergo grammaticalization seems to vary from one language to the other, and even from one period to the other, in the same language. As a result, within a family of languages, one language may be further down most grammaticalization clines than others, and thus appear more grammaticalized. This seems to be the case for English with respect to other Germanic languages (with Dutch not far behind, cf. König \& Gast 2007), and for French vis-à-vis other Romance languages: it has been shown that French is more grammaticalized than Italian, and Italian more grammaticalized than Spanish, by comparing for instance the paradigms of determiners, auxiliaries, or the expression of tense and mood (Lamiroy 1999, 2001, 2003, 2011, Carlier 2007, De Mulder 2001, De Mulder \& Lamiroy to appear). ${ }^{2}$

The questions we address in this paper are the following: Is it really possible to compare the degree of grammaticalization of languages? Is this scale of grammaticalization valid for all areas of the language? Do the paradigms of adpositions in Romance confirm the trend mentioned above? In order to answer these questions, we first evaluate different ways of comparing the degree of grammaticalization of languages (Section 2), then propose a definition of adpositions (Section 3) and describe the adpositional system found in Latin (Section 4). We go on to describe the adpositional systems of present-day French, Italian, Portuguese, Romanian and Spanish (Section 5), on the basis of existing lists (e.g. Fagard \& Mardale 2007, Fagard 2010). This description enables us to compare the degree of grammaticalization of adpositions in these languages. Finally, in order to check the validity of this scale of grammaticalization - based on a purely formal description - we compare in an onomasiological perspective the use of simple and complex adpositions in Romance, on the basis of modern (mostly spoken) corpora (Section 6), and conclude with suggestions for future research (Section 7).

\section{Comparing the (degree of) grammaticalization of languages}

We deal here with the first question asked in the introduction: Is it possible to compare the degree of grammaticalization of different languages? It is by now almost consensual to say that grammaticalization theory proposes an adequate framework for the description of language-internal changes involving the drift (to use Sapir's term) from lexicon to grammar. It is mostly used as a tool to describe the development of a given morpheme or construction, or the appearance of a new part of speech in a language, for instance determiners in Romance

\footnotetext{
${ }^{1}$ Or at least in all languages investigated to date in this perspective, to the authors' knowledge. Other phenomena include reanalysis and analogy, claimed to be "major mechanisms in language change" (Hopper \& Traugott 2003: 69), and marginally borrowing, which is attested for adpositions (e.g. Romanian başca from Turkish, 'international' via from Latin, etc.).

${ }^{2}$ In a different theoretical framework, Gawełko $(1999,2001)$ also points out the outstanding position of French, "less redundant” than other Romance languages (1999: 24). As he recalls, Brøndal (1939: 343) already noted the fact that French had a more grammaticalized set of prepositions than all other Romance languages, though Gawełko argues against this idea (Ibid.: 31-33).
} 
(Carlier 2007) or demonstrative adjectives vs pronouns in French (Marchello-Nizia 1995). Only recently have linguists started using this framework to compare the degree of grammaticalization of different languages. This new type of study entails a series of questions: we will try to determine in this contribution whether it is legitimate to compare languages in this way, and provide clues as to how such a comparison can be operationalized, i.e. how we can use a theoretical definition to measure the degree of grammaticalization on the basis of corpus data.

The first issue is whether such a comparison is legitimate. It is quite obvious that languages do not necessarily grammaticalize the same elements: what is grammatical in one language can be expressed lexically or not at all in another one (cf. evidentials (Aikhenvald 2004), to give just an example). This does not mean, however, that the latter is 'less grammaticalized'. In order to establish a ranking according to the degree of grammaticalization of a language as a whole, we would need - ideally - to make a list of all possible grammatical features, and check for each language which ones are indeed the result of grammaticalization processes. Moreover, even if we can do so, it is far from obvious that all categories should be given the same weight. For instance, should a language with more TAM markers and less deictic markers be considered more or less grammatical than a language with opposite features? It seems quite impossible to answer. What does seem possible, though, is to compare related languages, one category at a time (see De Mulder \& Lamiroy, to appear), or to compare the global tendency of related languages (Gawełko 2001: 397). For each grammatical category, we can evaluate and compare the degree of grammaticality of two languages.

The second issue - how to operationalize this kind of comparison - is also delicate. There are various ways to do so. In previous studies, the main factor called upon is the degree of paradigmatization of a given word class (Lamiroy 2011, De Mulder \& Lamiroy to appear), i.e. its size and obligatory vs optional nature (ibid.), following Lehmann's (1995: 164) idea that a situation in which the speaker has a free choice between various elements on the basis of his communicative intentions is less grammaticalized than a situation in which his choice is systematically constrained.

Concerning adpositions, when comparing two languages, we can hypothesize that one of them will display at least one of the following features with respect to the other (a-d): ${ }^{3}$

a) a greater number of simple adpositions;

b) a more grammaticalized set of simple adpositions;

c) a more specialized class of adpositions, cut off formally and distributionally from adverbs, conjunctions, preverbs, etc. ${ }^{4}$;

d) a greater number of adpositions in general.

Is one of these features a relevant indication of the language's (greater) degree of grammaticalization? In what follows, we will see that French is probably most grammaticalized among Romance languages, for all four features. It remains to be seen how we determine which adpositions are most grammaticalized; in order to do so, we need a precise definition of adpositions, which is given in the following section.

\footnotetext{
${ }^{3}$ Note that we view adpositions as grammatical elements, though it is quite clear to us that grammaticality, in this respect, is a matter of degree: adpositions are less grammatical (as a whole) than, say, case marking on nouns or TAM marking on verbs, but more grammatical than nouns or verbs.

${ }^{4}$ We mean here that, when used as an adposition, a given morpheme which may have been used earlier as a verb, an adverb or a noun will have a different distribution and different formal characteristics. This does not mean that it can no longer be used with its original function.
} 


\section{A working definition of adpositions}

Traditional definitions of grammar often present grammatical elements as members of closedclass paradigms. Elements which do not fit in well because they annoyingly display features of two different categories, or not all features of one category, can then be described as 'poor' instances of the category in question: 'pseudo' adpositions, 'improper' adverbs, etc. In our view, a prototypical framework more adequately describes such classes (Company Company 2002): grammatical categories are then seen as heterogeneous paradigms containing elements which display the category's prototypical features to various degrees. In the case of adpositions, we expect to find a core of prototypical adpositions, a set of less prototypical elements and finally a set of elements which share only some (proto)typical features of adpositions. The prototypical framework implies, besides, that these distinctions are not clearcut, and that many elements can be shown to be in-between these subcategories.

Many linguists have worked on adpositions, and proposed a series of features which present partial overlap (among others, Rizzi 1988, Van Riemsdijk 1990, Zwarts 1997, Gaatone 2001, Di Meola 2000, Melis 2003, Abeillé et al. 2003, Cuniţă 2004, Ciobanu \& Nedelcu 2008, Mardale 2009, Hagège 2010). Drawing on these studies, we will take (i) as a working definition of adpositions. This definition consists of a series of features ranging from syntax (a, b, c) to semantics (d), morphology (e) and frequency (f).

(i) An adposition

(a) is used as the head of an adpositional phrase

(b) typically takes a noun phrase as its complement

(c) syntactically relates its complement to a unit higher up in the clause hierarchy

(d) semantically qualifies this relation

(e) formally consists of a simple morpheme, and is short (no more than two

syllables)

(f) is frequent

A prototypical adposition is expected to present all features. Note that many adpositions will not satisfy all criteria, at least not in all contexts of use. ${ }^{5}$ Besides, the above features include inherent, empirically observable characteristics (e, f) and others which can only be found as the result of the linguist's analysis, on the basis of previous theoretical assumptions. For this reason, the operationalization of this definition will have to rely heavily on observable features, i.e. (b), (d), (e) and (f) (and, to a lesser extent, (c)).

This definition is valid in synchrony. From a diachronic point of view, one would have to add that adpositions are sometimes borrowed, but are much more frequently the result of a grammaticalization process. Even though linguists might disagree as to what weight must be given to each factor, it seems consensual to say that the grammaticalization of a morpheme with respect to the source construction involves mainly but not always phonetic attrition, semantic weakening and morpho-syntactic loss of flexibility. These phenomena can operate on different types of elements and have, consequently, different outcomes: the grammaticalization of a construction may yield a complex adposition; that of a complex adposition may yield a simple adposition; finally, that of a simple adposition yields what we will call a 'functional' adposition, which may in turn grammaticalize further (see below, (ii)). This evolution is gradual, so that it is sometimes a complex matter to determine whether a

\footnotetext{
${ }^{5}$ For instance, concerning feature (a), a functional adposition such as to in I gave a book to Paul may be analysed as not being the head of an adpositional phrase; concerning feature (b), an adposition such as from in I ran from behind the school / from there does not always take a noun phrase as its complement, but the adpositional phrase behind the school or the adverb there; the same can be shown for features (c)-(f).
} 
given construction is a free construction or a complex adposition, or whether a simple adposition is functional or not.

We describe each subtype in section 5; our point here is that, if determining the degree of grammaticalization of a morpheme is sometimes complex, it is even more so if one is looking at a whole paradigm. Keeping to adpositions, there are languages with a very small subset of simple (highly grammaticalized) adpositions - sometimes only one, as in Tzeltal (Brown 2006; Grinevald 2006), Samoan, Burmese, Siamese, Lipke or Tagalog (none in Klamath, cf. DeLancey 2005, and a few other languages, cf. Hagège 2010: 68). Other languages have just a few (Longgu), a few dozens (Portuguese, cf. Jakubowicz Batoréo 2000: 496), or more (fifty or so adpositions, for instance, in English). From this point of view, we have to determine which Romance language has undergone most renewal, along two different lines of evolution: which language has (a) renewed its adpositional system the most, and (b) grammaticalized furthest its already existing adpositions? In order to answer question (a), we first need to describe the adpositional system of Latin: this is the object of the next section. We will base our answer to question (b) by measuring the degree of grammaticalization of each adposition with respect to the grammaticalization cline usually given for adpositions (see e.g. Lehmann 1985, Svorou 1994: 101 sqq., Fagard 2006):

(ii) complex adposition $>$ simple adposition $>$ functional adposition $>$ case affix $>\emptyset^{6}$

\section{Latin adpositions and paradigm renewal}

Romance languages did not create their adpositional paradigms out of nothing: there were already adpositions in Latin. Were they comparable to paradigms of adpositions in Romance? In order to answer this question, it will be helpful to describe briefly the paradigm of adpositions in Latin.

\subsection{Latin adpositions}

Latin had quite a few adpositions, as the reader can judge by himself on the basis of Table 1 , which lists a total of 80 different morphemes. However, as indicated in section 3, we expect these adpositions to be heterogeneous in form and function. Indeed, some Latin adpositions were also used as preverbs (for instance per, $a d, a b, o b$, in, ex, cis, cum, de, sē, uls, cf. Meillet 1948: §784, Leumann, Hoffmann \& Szantyr 1965; for their preverbal uses, see Haverling 2003), while others were also used as adverbs (adversus, ante, circa, circum, citra, contra, coram, extra, intra, infra, juxta, post, prope, propter, supra), others yet as both adverbs and preverbs (post, ante, sub, super, apud). Some of these only had a limited functional resemblance to the rest of the category, having rare uses as adpositions, and not being fully grammaticalized: these adpositions were presumably recent additions to the paradigm, such as coram 'in the presence of', causa 'because of', gratia 'thanks to', ergo 'because of', erga 'in front of, concerning, for', penes 'at the hands of', procul 'far from', circum 'near', tenus 'all the way to', fine (and fini) 'all the way to', foras (and foris) 'out of' (Meillet 1948: 521). ${ }^{7}$ This

\footnotetext{
${ }^{6}$ Note that this is but one possible outcome of the further grammaticalization of adpositions. Other outcomes include the grammaticalization of functional adpositions into determiners, such as French de, or into complementizers (Noonan 2007: 57), among other things (see Hagège 2010).

${ }^{7}$ Note that these constructions are not equivalent and need not have undergone grammaticalization to the same extent or along the same lines. For instance, gratia or causa can be considered adpositions only when they combine with a noun in the genitive, then constituting an adjunct as a whole; the use of foras or circum is quite different, since these items function as adverbs, and thus as adjuncts, whether they combine with a noun or not. Their sole commonality, in our view, is that they are distributionally equivalent to adpositions, without having grammaticalized fully.
} 
last class of adpositions is mainly composed of nouns in a fixed form, most frequently the ablative, which always govern a complement in the genitive, at least in the first stages of their grammaticalization, whereas some adpositions of the other subclasses govern more than one case (Sausy 1992: 177-178). Table 1 below illustrates the heterogeneity of Latin adpositions, on the basis of the criteria given in section 3, with a core class of only 19 morphemes (with frequent use, always preposed, cf. Hagège 2010: 117, and reduced phonetics), out of the 80 which have adpositional uses.

\begin{tabular}{|l|l|}
\hline Type of adposition & Forms \\
\hline 'prototypical' adpositions & ( \\
\hline $\begin{array}{l}\text { recent grammaticalizations (some } \\
\text { used as adverbs and adpositions; } \\
\text { less frequent) }\end{array}$ & $\begin{array}{l}\text { absque, adversum, adversus, apud, contra, cum, de, ex, in, infra, ob, per, post, } \\
\text { circum, cis, citra, clam, coram, deintus, denetro, desub, desubtus, } \\
\text { erga, ergo, extra, foras, foris, gratia, insuper, inter, juxta, merito, } \\
\text { palam, penes, praeter, procul, prope, propter, retro, secundum, } \\
\text { subinde, subter, subtus, supra, tenus }\end{array}$ \\
\hline $\begin{array}{l}\text { atypical adpositions (either archaic, } \\
\text { not completely grammaticalized or } \\
\text { late; still less frequent) }\end{array}$ & $\begin{array}{l}\text { abusque, adusque, cata, circiter, exadversum, exsuper, fine, fini, } \\
\text { intra, intus, pone, pridie, propius, proxime, sē(d), secus, simul, } \\
\text { uls, ultra, usque, versus, vitio }\end{array}$ \\
\hline
\end{tabular}

Table 1: Simple Latin adpositions.

Some of these morphemes disappeared more or less completely in the transition from Latin to Romance, such as coram, ob, etc. Others survived only locally, like versus in Gallo- and ItaloRomance. Only a few are still found in more or less all Romance languages, including in, $a d$, de, per and pro.

\subsection{Loss and renewal}

The transition from Latin to Romance resulted in a partial reduction of the original paradigm. We will not dwell here on this evolution, since we do not plan to account for the differentiation of Romance languages in diachrony, but to describe its results in synchrony. ${ }^{9}$ Suffice it to say that Romance languages replaced Latin adpositions by new ones mostly through grammaticalization processes. Some of these were local, e.g. Provençal doumaci 'thanks to' (lit. 'god-grace', i.e. “thank god”), French chez 'at the house of, in the works of', while others were quite widely spread, like Catalan, French, Provençal and Romansh durant (with various spellings in Romansh: duront, durànt, etc.), Italian, Spanish and Portuguese durante 'during', which is also present as a loan-word in Sardinian duranti: only Romanian seems to have no similar construction, using instead în timpul "in the time" followed by a noun phrase in the genitive. ${ }^{10}$ Another important phenomenon was the grammaticalization of simple Latin adpositions into functional adpositions, attested in all Modern Romance languages - even in Medieval Romance.

\footnotetext{
${ }^{8}$ Some of these adpostions also display uses as preverbs: they might therefore be considered less prototypical (as adpositions).

${ }^{9}$ For a more detailed description of this evolution, see Fagard (2010).

${ }^{10}$ For some of these items, one might wonder whether they are sufficiently grammaticalized to qualify as full adpositions: they could also be considered as lexical items, which underwent not a process of grammaticalization but one of lexicalization. In our view, even for items which did not reach 'full' adpositional status, such as oiant, veant frequent in phrases like oiant toz, veant toz (lit. "(everyone) hearing, seeing"), there is a process of lexicalization, which can be considered as the first step of a grammaticalization process (Prévost \& Fagard 2007).
} 


\section{Paradigms of adpositions in Romance}

The result of the renewal sketched out in the previous section is that Romance languages all have adpositional systems which are partly based on Latin adpositions and partly the result of the more recent grammaticalization of elements from various categories. As predicted by the theoretical description in section 3, Romance adpositions are very heterogeneous, with different classes of adpositions in each language (cf. e.g. Melis 2003: 41-43, for French adpositions). This is because they do not all display the entire list of features outlined in (i): some are more prototypical than others. Besides, while it is generally possible to determine whether a given adposition is more or less grammaticalized than another one, it seems impossible to establish clear-cut category boundaries between very grammaticalized, less grammaticalized and hardly grammaticalized morphemes. As with other parts of speech, grammaticality is a matter of continuum rather than of discrete categories (Di Meola 2000: 144 sqq.).

\subsection{Paradigms}

In each language, a small class of adpositions always take a complement, which typically is a noun phrase but can also be an adpositional phrase, an adverb or even a whole clause. ${ }^{11}$ These highly grammaticalized adpositions, which we call functional adpositions (cf. however Mardale 2009 for a stricter definition of functional adpositions), make up a very limited set in each Romance language (Table 2).

\begin{tabular}{|c|c|c|c|c|}
\hline Spanish & French & Italian & Portuguese & Romanian \\
\hline $\begin{array}{c}\text { a, de, en, por, } \\
\text { para, con }\end{array}$ & $\begin{array}{c}\text { à, de, en, par, } \\
\text { pour, avec, dans }\end{array}$ & $\begin{array}{c}\text { a, da, di, in, con, } \\
\text { per }\end{array}$ & $\begin{array}{c}\text { a, de, em, por, } \\
\text { para, com }\end{array}$ & a, de, la, pe, în, cu \\
\hline
\end{tabular}

Table 2: Highly grammaticalized adpositions in Romance.

These morphemes display a very high frequency, associated with almost all prototypical features of adpositions, except feature (a) in definition (i) (Section 3), which is not always satisfied. As a result of the fact that the definitional features of adpositions are not always present, membership of this category is a matter of degree: some of the adpositions listed above are more grammaticalized than others. For instance, one common feature of these highly grammaticalized adpositions is their greatly bleached meaning and corollary polysemy, but this is a gradual feature, as illustrated by the fact that it seems more applicable to French $a$ and de than to avec. Another common feature, less prototypical of adpositions, is the fact that they have various 'grammatical' uses, introducing for instance the genitive or dative object (2), ${ }^{13}$ along with 'predicative' uses of $d e$ (3), the dative (4), the patient of a passive (5) or the introduction of a given verb's complements (6a-c). We illustrate below a few of these features

\footnotetext{
${ }^{11}$ Cf. Melis (2003: 12-17), who considers these complements to be distributional equivalents of a noun phrase, or Hagège (2010: 58), who provides a hierarchy of more or less frequent terms governed by adpositions, from personal pronouns and noun phrases (most frequent) to subject-predicate associations (least frequent).

${ }^{12}$ We could add here the adposition sur (Table 3), which seems to have been undergoing a process of further grammaticalization since the $19^{\text {th }}$ century, with increasing frequency and clear semantic bleaching, especially in a few specific contexts. For instance, sur introduces the complements of a growing number of verbs (see De Mulder \& Vanderheyden, 2000).

${ }^{13}$ Generally expressed by the adposition $d e / d i$, sometimes by a/à, as in example (2). Note that the semantic relation could be seen as genitive (a rough equivalent to John's car) or dative (glossed as she's being friendly to us both).
} 
(for a more developed analysis, see Melis 2003). Paradoxically, in their most grammatical uses, these items end up behaving less prototypically as adpositions, and may actually develop into other grammatical morphemes such as complementizers, determiners, etc., as we saw with the grammaticalization cycles given above in (ii).

$\begin{array}{lllllllll}\text { madame } & \text { brumer } & \text { c' } & \text { est } & \text { une } & \text { copine } & \text { à } & \text { nous } & \text { deux } \\ \text { missis } & \text { Brumer } & \text { DEM } & \text { be.PRS.3SG } & \text { INDF.F.SG } & \text { friend } & \text { at } & \text { we.OBJ } & \text { two }\end{array}$
'Missis Brumer is a friend of the two of us.' (Clapi, Bielefeld, 225-230)

(3)

$\begin{array}{lllll}\text { - não } & \text { é } & \text { perigoso, } & \text { o } & \text { javali? } \\ \text { NEG } & \text { be.PRS.3SG } & \text { dangerous.M.SG } & \text { DEF.M.SG } & \text { boar.SG }\end{array}$

- ah! coitado (sic) dos bichos! perigosos somos nós! oh! poor.M.SG of.DEF.M.PL beast.PL dangerous.M.PL be.PRS.1PL we.SBJ

'- Aren't boars dangerous?

- Oh, poor beasts! We’re dangerous, not them!' (Corpus do Português, 1989, Lisboa, Cartografia Portuguesa)

(4) quindi dare a Tizio per togliere a Caio non c' è so give.INF at Titius to take.INF at Caius NEG there be.PRS.3sG

nessun vantaggio

NEG.INDF.M.SG advantage.SG

'So if you give to Titius what you took from Caius, what is the use?' (Badip, RE22B)

(5) Pues me gustan los libros que hablan sobre mujeres, Well me.OBJ please.PRS.3SG DEF.M.PL book.PL REL speak.PRS.3PL on woman.PL

$\begin{array}{llllllll}\text { feministas } & \text { y } & \text { eso, } & \text { escritos } & \text { por } & \text { mujeres } & \text { y } & \text { que } \\ \text { feminist.F.PL } & \text { and } & \text { DEM.M.SG } & \text { write.PST.M.PL } & \text { by } & \text { woman.PL } & \text { and } & \text { REL }\end{array}$

cuenten historias de mujeres.

tell.PRS.SBJV.3PL story.PL of woman.PL

'Well, I like books that talk about women, feminists and all that, written by women and which tell womens’ stories.' (Crea, Grupo G 7, Magisterio, España)

(6a)
ne-am
întâlnit
cu emil la gară
REFL.1PL.OBJ-have.PRS.1PL meet.PST with Emil at
station.SG

'We met Emile at the station.' (Ruxăndoiu, dialog La Brăila, la vie)

$(6 \mathrm{~b})$

$\begin{array}{llllll}\text { m-am } & \text { întâlnit } & \text { cu } & \text { ea } & \text { şi } & \text { cu } \\ \text { REFL.1SG.OBJ-have.PRS.1SG } & \text { meet.PST } & \text { with } & \text { PRO.F.G.SG } & \text { and } & \text { with }\end{array}$

maică-sa

mother.SG-POSS.F.3SG

'I met her and her mother.' (Ruxăndoiu, dialog Într-o cameră de hotel)

$\begin{array}{lllllll}\text { (6c) } & \text { s-a } & \text { întâlnit } & \text { cu } & \text { ea } & \text { la: } & \text { prefectură } \\ & \text { REFL.3SG-have.PRS.3SG } & \text { meet.PST } & \text { with } & \text { PRO.F.G.SG } & \text { at } & \text { precinct.SG }\end{array}$

'He met her at the precinct.' (Ruxăndoiu, dialog În redacţie)

\footnotetext{
${ }^{14}$ We arbitrarily gloss the Romanian genitive-dative as 'G', for convenience, since they are homonymous in nouns.
} 
Finally, as a rule ${ }^{15}$, they cannot be used as adverbs; compare (7a) with (7b):

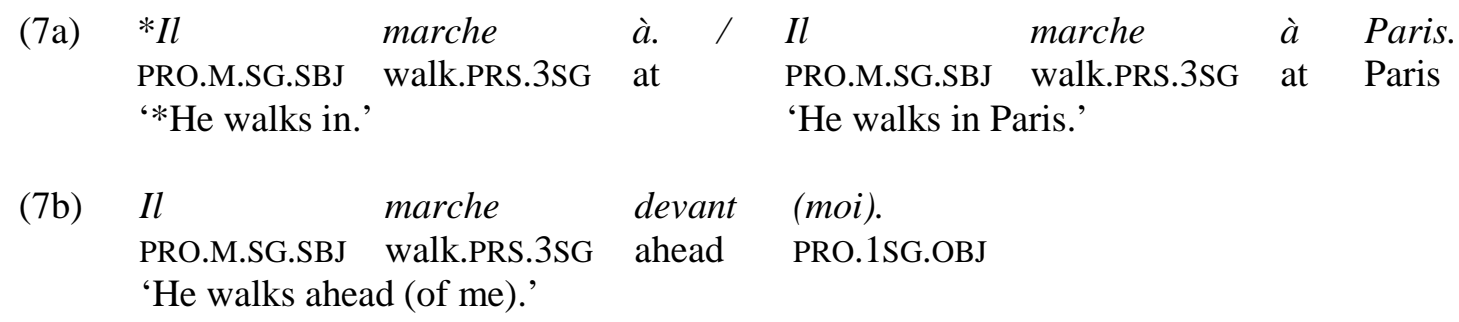

The degree of grammaticalization of these adpositions is reflected in their frequency, their degree of semantic bleaching and foremost the variety of their uses: the least grammaticalized (cu, con, com, avec) only have few 'grammatical', i.e. syntactically bound uses, typically the introduction of verb complements (ex. (6a-c)).

The next series of adpositions, in terms of degree of grammaticalization, is that of 'lexical' adpositions. They take a complement which is not introduced by a functional adposition; however, in some cases, this complement is not lexically realized. They make up a larger series, in each language, and display a lesser degree of grammaticalization. They are characterized by only some of the typical features of adpositions (cf. (i)). For instance, adpositions such as côté, question, etc. only take bare nouns as complements, to the exclusion of real NPs (8a-b):

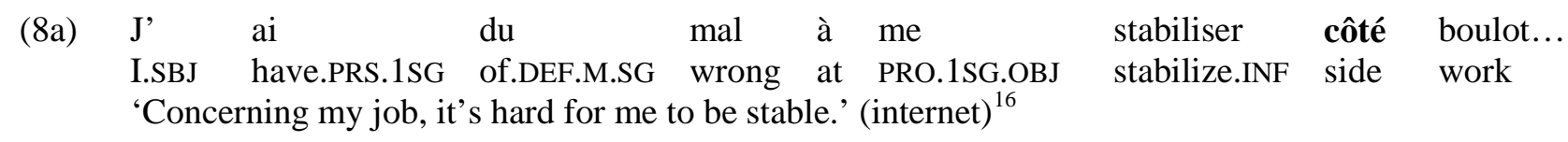

(8b) Là question travail ça valait mieux que (inaud.) there question work DEM.M.SG be.good.PST.3SG better than (inaudible) 'At that point, as far as the job was concerned, it was better than...' (Clapi, At the dentist's $\left.\mathrm{n}^{\circ} 1,2003\right)$

Other morphemes, such as contro, derrière can be used either as adpositions or as adverbs. Examples (9a-b) illustrate the difference between an adposition with no complement (9a, in which contro can have a complement: chi vota contro questa decisione? 'who votes against this decision?') and an adverb (9b, where derrière cannot have a complement; derrière 'behind' is used to mean 'in the back of the field', but 'the field' cannot be used as a complement in this case).

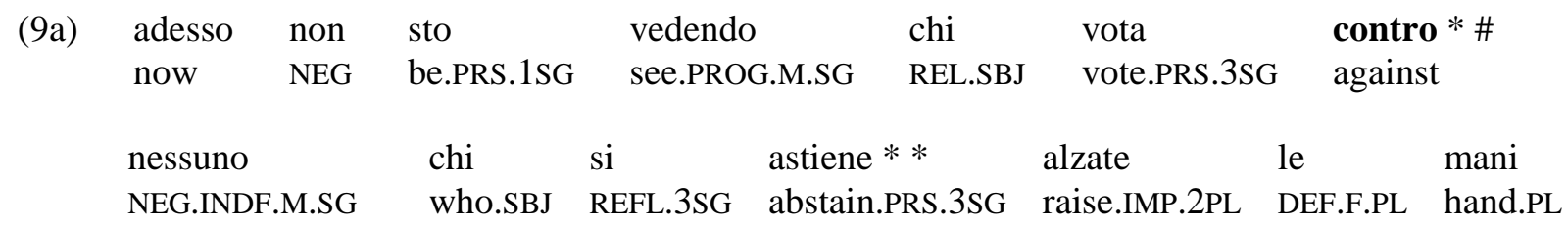

\footnotetext{
${ }^{15}$ There are exceptions, for instance stylistically marked (or coordinated) uses in which the complement can be absent. Some of these adpositions can have uses with a 'zero' or 'null' complement, in particular pour and avec in French.

${ }^{16}$ Written August 3 ${ }^{\text {rd }}$, 2005; accessed September 2010 (http://www.yabiladi.com/forum/stabiliser-cote-boulot-1677162.html).
} 
gli astenuti prego

DEF.M.PL abstainer.M.PL please

'Now I can't see who's voting against. No one. Who abstains? Anyone abstaining please raise your hand.' (Badip, MC111B)

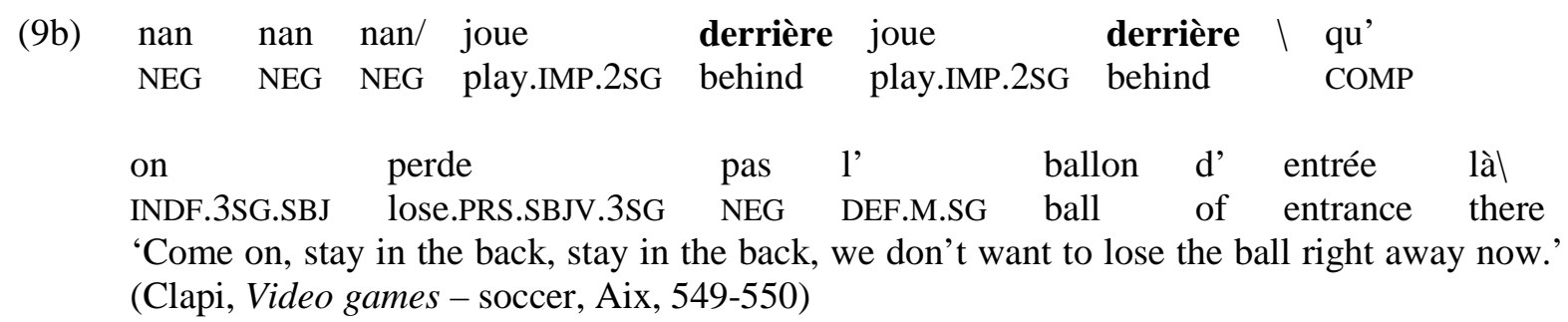

Some of these adpositions are only used in specific genres, literary or other: this is the case of French jouxte 'near, next to' (old, lit. or technical term), Spanish cabe 'near' (poetic), Italian avverso 'against' (old, technical) and many others. Listing simple adpositions exhaustively without including morphemes which are only rarely used as such is therefore quite problematic. Another problem is to decide what makes a simple adposition 'simple': in some cases, though the univerbation of a complex adposition has phonetically taken place, as shows its lack of variation, the resulting morpheme is still a complex one - in writing. This is the case for French à travers, par-devers, par-dessus, par-dessous, etc., which never allow insertions or modifications, as illustrated by the comparison of (10a-b). This justifies in our view the inclusion of à travers and the like in the paradigm of simple adpositions; the fact that it is quite impossible to gloss independently à and travers is also an indication that the univerbation has indeed taken place.

(10a) À côté de lui $\rightarrow$ à son côté at side of him at POss.M.3SG side

'By his side.'

(10b)

$\begin{array}{llllll}\begin{array}{l}\text { à travers lui } \\ \text { through him }\end{array} & \rightarrow & * a ̀ & \text { son } & \text { travers } \\ \text { 'Through him.' } & & \text { at } & \text { POSS.M.3SG } & \text { (intranslatable) }\end{array}$

Taking into account all these elements, it can be shown that simple adpositions form a large set, as can be seen in Table 3 below.

\begin{tabular}{|l|l|l|l|l|l|}
\hline & Spanish & French & Italian & Portuguese & Romanian \\
\hline 'prototypical' & ante, bajo, & (mis) à part, à & circa, dopo, & após, & (pe) lângă, \\
adpositions & contra, desde, & travers, après, & durante, & consoante, & sub, în, spre, \\
(never used & durante, entre, & avant, chez, & eccetto, entro, & dêsde, & cu, peste, fără, \\
with another & excepto, hacia, & concernant, & fra, malgrado, & durante, & între, până, \\
adposition & hasta, incluso, & contre, d’après, & mediante, & excepto, & contra, graţie, \\
introducing & mediante, & d'entre, de par, & salvo, & mediante, & datorită, \\
their & salvo, según, & depuis, derrière, & secondo, & perante, & mulțumită, \\
complement, & sin, sobre, tras & dès, devant, & senza, su, tra, & salvo, & drept, versus, \\
except in Italian & & durant, entre, & tramite, & segundo, & via, başca, \\
with personal & & envers, environ, & tranne, verso & sem, sob, & dintre, pentru, \\
pronouns; & & excepté, jusqu’à, & & sobre & prin, printre, \\
\hline
\end{tabular}




\begin{tabular}{|c|c|c|c|c|c|}
\hline $\begin{array}{l}\text { 'frequent' use in } \\
\text { all registers) }\end{array}$ & & $\begin{array}{l}\text { malgré, outre, } \\
\text { par devers, par- } \\
\text { delà, par- } \\
\text { derrière, par- } \\
\text { dessous, par- } \\
\text { dessus, par- } \\
\text { devant, parmi, } \\
\text { passé, pendant, } \\
\text { sans, sauf, selon, } \\
\text { sous, sur, vers }\end{array}$ & & & $\begin{array}{l}\text { după, înspre, } \\
\text { împotriva }\end{array}$ \\
\hline $\begin{array}{l}\text { adpositions } \\
\text { sometimes used } \\
\text { intransitively }{ }^{18}\end{array}$ & junto & $\begin{array}{l}\text { hors, en face, en } \\
\text { dessous }\end{array}$ & $\begin{array}{l}\text { appresso (a), } \\
\text { attraverso (a), } \\
\text { contro (a), } \\
\text { davanti (a), } \\
\text { dentro (a, da, } \\
\text { di), dietro (a), } \\
\text { dinanzi (a), } \\
\text { fin(o) (a / da), } \\
\text { fuori (da, di), } \\
\text { innanzi (a), } \\
\text { intorno (a), } \\
\text { lungo (a), } \\
\text { oltre (a), } \\
\text { presso (a), } \\
\text { rasente (a), } \\
\text { sopra (a), } \\
\text { sotto (a), } \\
\text { vicino (a) }\end{array}$ & $\begin{array}{l}\text { até, } \\
\text { conforme, } \\
\text { fora, trás }\end{array}$ & $\begin{array}{l}\text { după, peste, } \\
\text { sub }\end{array}$ \\
\hline $\begin{array}{l}\text { literary, } \\
\text { specialized or } \\
\text { not completely } \\
\text { grammaticalized } \\
\text { adpositions }\end{array}$ & $\begin{array}{l}\text { allende, cabe, } \\
\text { cuando, } \\
\text { empós, entro, } \\
\text { menos, pro, } \\
\text { so, tipo, } \\
\text { versus, via }\end{array}$ & $\begin{array}{l}\text { attendu, côté, ès, } \\
\text { hormis, jouxte, } \\
\text { jusque, lez, } \\
\text { moyennant, } \\
\text { niveau, } \\
\text { nonobstant, } \\
\text { plein, question, } \\
\text { suivant, } \\
\text { touchant, vu }\end{array}$ & $\begin{array}{l}\text { appo, } \\
\text { avverso, } \\
\text { giusta, } \\
\text { nonostante }\end{array}$ & $\begin{array}{l}\text { afora, dês, } \\
\text { menos, } \\
\text { senão, } \\
\text { tirante, } \\
\text { visto, tipo }\end{array}$ & gen, tip ${ }^{19}$ \\
\hline
\end{tabular}

Table 3: Lexical adpositions in Romance (simple and complex but unanalysable morphemes, e.g. à travers, jusqu'à)

Finally, there is in each language a large series of complex constructions which take on syntactic and semantic functions similar to those of simple adpositions. These constructions, which we will call complex adpositions, can follow various patterns (Melis 2003: 106 sqq.), but generally consist of a lexical nucleus, generally a noun, preceded and/or followed by (most often functional) adpositions, e.g.

\footnotetext{
${ }^{17}$ Note that some of these morphemes can also be used as adverbs, for instance.

${ }^{18}$ This category needs to be refined, as it contains elements which are mostly transitive and others which are mostly intransitive. This is no simple task, since these variations can be diatopical (for instance French en face (de)), diachronic (e.g. Modern Spanish detrás de vs Medieval Spanish tras), etc.

19 Adpositions such as Romanian gen, tip, French genre, Italian, Portuguese or Spanish tipo 'like, for instance' are actually closer to hedges. However, from a distributional point of view, they present some similarities with adpositions - more or less depending on language and period - which is why we included them in this account.
} 
[Adposition $(+$ Determiner $)+$ Noun/Adverb/Adjective/Participle/Infinitive/.. + Adposition].

The most frequent patterns observed in Romance languages are the following:

[Adposition + Noun + Adposition],

[Adposition + Determiner + Noun + Adposition],

[Adverb + Adposition]

Note that the lexical item which forms the core of the construction (noun, adverb, etc.) generally loses its referential potential or part of its meaning once it is integrated in a fixed construction. Different types of complex adpositions are illustrated in Table 4 below, which does not aim at exhaustivity, neither for each construction nor for the types of constructions.

\begin{tabular}{|c|c|c|c|c|c|}
\hline Pattern & Spanish & French & Italian & Portuguese & Romanian \\
\hline $\begin{array}{l}\text { Adposition } \\
+ \text { Noun + } \\
\text { Adposition }\end{array}$ & $\begin{array}{l}\text { a camino } \\
\text { de, a través } \\
\text { de, de } \\
\text { acuerdo } \\
\text { con }\end{array}$ & $\begin{array}{l}\text { à cause de, à côté } \\
\text { de, à défaut de }\end{array}$ & $\begin{array}{l}\text { a malgrado di, } \\
\text { a causa di, a } \\
\text { confronto di, } \\
\text { da parte di }\end{array}$ & $\begin{array}{l}\text { a despeito de, } \\
\text { a fim de, de } \\
\text { redor de }\end{array}$ & $\begin{array}{l}\text { cu privire la, în } \\
\text { curs de, în ajun de, } \\
\text { în comparaţie cu, } \\
\text { în decurs de, în } \\
\text { legătură cu, în loc } \\
\text { de, în relaţie cu, la } \\
\text { nivel de, pe bază } \\
\text { de, pe timp de }\end{array}$ \\
\hline $\begin{array}{l}\text { Adposition } \\
+ \\
\text { Determiner } \\
+ \text { Noun + } \\
\text { Adposition }\end{array}$ & $\begin{array}{l}\text { al revés de, } \\
\text { en el } \\
\text { interior de }\end{array}$ & $\begin{array}{l}\text { au-dessus de, au } \\
\text { sein de, du côté } \\
\text { de, au moyen de }\end{array}$ & $\begin{array}{l}\text { all'opposto di, } \\
\text { all'interiore di }\end{array}$ & $\begin{array}{l}\text { no meio de, } \\
\text { no fundo de }\end{array}$ & $\begin{array}{l}\text { (structurally } \\
\text { impossible) }\end{array}$ \\
\hline $\begin{array}{l}\text { Adverb + } \\
\text { Adposition }\end{array}$ & $\begin{array}{l}\text { encima de, } \\
\text { debajo de, } \\
\text { delante de }\end{array}$ & $\begin{array}{l}\text { en-dessous de, à } \\
\text { côté de, en-dehors } \\
\text { de }\end{array}$ & $\begin{array}{l}\text { accanto a, } \\
\text { addosso a, } \\
\text { attorno a }\end{array}$ & $\begin{array}{l}\text { abaixo de, } \\
\text { acerca de, } \\
\text { acima de, } \\
\text { cerca de }\end{array}$ & $\begin{array}{l}\text { în afară de, alături } \\
\text { de, departe de, } \\
\text { vizavi de, înainte } \\
\text { de, împreună cu }\end{array}$ \\
\hline
\end{tabular}

Table 4: Recurrent patterns of complex adpositions in Romance.

A specific characteristic of Romanian is that, owing to the existence of a partial case system, complex adpositions can follow other patterns, illustrated in Table 5 below.

\begin{tabular}{|l|l|l|}
\hline Schema & Spatial constructions & Other constructions \\
\hline $\begin{array}{l}\text { Adposition } \\
+ \text { Noun + }\end{array}$ & $\begin{array}{l}\text { în urma, în mijlocul, în limita, în jurul, la } \\
\text { marginea, la nivelul, pe parcursul, pe raza, pe } \\
\text { (+ Genitive) }\end{array}$ & $\begin{array}{l}\text { în baza, în numele, în privinţa, în } \\
\text { vederea, din cauza, din momentul, } \\
\text { pe vremea }\end{array}$ \\
\hline $\begin{array}{l}\text { (Adposition } \\
+ \text { ) Adverb + }\end{array}$ & în afara, dedesubtul, înapoia & \\
$\begin{array}{l}\text { Determiner } \\
\text { (+ Genitive) }\end{array}$ & & \\
\hline
\end{tabular}

Table 5: Other types of complex adpositions in Romanian

\subsection{Adpositional categories and pace of grammaticalization}

The data presented above clearly indicate that Romance languages have quite similar categories of adpositions. However, there are differences. For instance, the number of simple adpositions varies greatly from one language to the other, with many more adpositions in French (around 40) than in all others (from 13 to 23). Types of complex adpositions also vary: in Spanish and Portuguese, the pattern [(Adposition +) Adverb + Adposition] is very frequent, much more than in French or Italian, which display other patterns; in Romanian, other 
patterns are frequent on account of the case system, and the class of complex adpositions thus seems much less grammaticalized (or lexicalized). We could, provisionally, claim French to be the most grammaticalized language for all four criteria given in section 2, with a very large set of simple adpositions; besides, it has relatively rigid patterns of complex adpositions ${ }^{20}$. It is followed by Italian, which has a large set of simple adpositions but many adpositions displaying various types of variation, such as the presence of $d i$ when the complement is a pronoun, or the presence of the adposition $a$ which governs the complement, as in dietro all'albero "behind (at) the tree". Italian also has patterns of complex adpositions. Next come Spanish and Portuguese, with small sets of simple adpositions, and recurrent patterns of complex adpositions. Finally, Romanian adpositions are quite clearly less grammaticalized, since they do not ensure alone the syntactic link with their complement: this link is also the result of case marking. Thus, although Romanian has relatively many simple adpositions, they are all to be considered discontinuous morphemes, and therefore less grammaticalized. The existence of more varied patterns of complex adpositions confirms this status of Romanian. Before reaching any conclusion as to the degree of grammaticalization of these classes of adpositions, we will have to take other elements into account.

\section{An onomasiological approach}

\subsection{A 'basic' set of adpositions?}

We believe it is necessary to go beyond a purely paradigmatic view of the language; as pointed out a.o. by Schøsler (2008), usage is more important than the lexical distribution itself $^{21}$. For this reason, we decided to study the use of Romance adpositions with an onomasiological perspective. In order to do this, we propose to analyse the expression of a subset of contrastive spatial configurations given in Figures a-h by simple and/or complex adpositions.

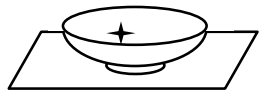

Figure a (IN(SIDE))

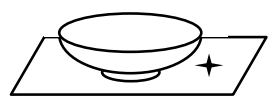

Figure b (OUT(SIDE))

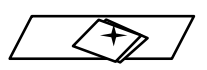

Figure c (ON)<smiles>C1=C2CCCC2C1</smiles>

Figure f (IN FRONT OF)

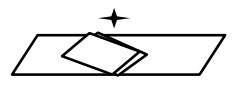

Figure d (ABOVE)

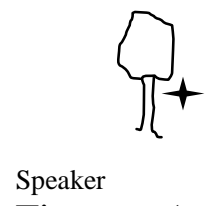

Speaker

Figure g (BEHIND)

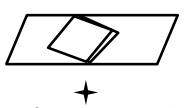

Figure e (UNDER)

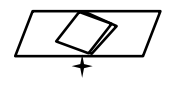

Figure e' (UNDER) $)^{22}$

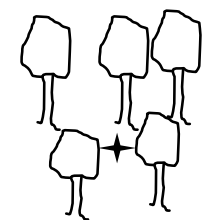

Figure h (BETWEEN / AMONG)

\footnotetext{
${ }^{20}$ We believe this to be an indication of their greater degree of grammaticalization - the less a pattern is flexible, the more entrenched and grammaticalized it is.

${ }_{21}$ Gawełko (1999: 20) also stresses the need to go beyond purely formal criteria for the classification of Romance languages.

22 This type of spatial configuration was left aside, on account of the fact that no Romance language distinguishes between Figures e and e' (i.e. under with vs without contact).
} 
We have seen in section 3 that a simple adposition is more grammatical than a complex one. Our working hypothesis, which is admittedly intuitive, is as follows:

The more a language uses simple (rather than complex) adpositions to express 'basic' configurations, the more its adpositional system is grammaticalized.

The global degree of grammaticalization of a language could then be measured by the number of basic spatial configurations which it expresses with a grammatical(ized) item or construction. Some authors have claimed the existence of semantic universals (e.g. Wierzbicka 1988), or written that "the simplest spatial notions are topological - concepts of proximity, contiguity, containment” (Piaget \& Inhelder 1956, apud Levinson et al. 2003: 485). This claim is linked to the much discussed idea that, among spatial adpositions, those expressing configurations such as IN, ON and UNDER are learned first in language acquisition (Johnston \& Slobin 1979, Hickmann 2007) ${ }^{23}$. However, our position is quite different: for one thing, it seems that children do not always acquire spatial adpositions first (Morgenstern \& Sekali 1997: 210, Hallan 2001: 115), and that the order of acquisition of new words might be better accounted for by frequency (cf. Bybee \& Hopper 2001). Besides, as Evans \& Levinson put it, "languages differ so fundamentally from one another at every level of description (sound, grammar, lexicon, meaning) that it is very hard to find any single structural property they share" (2009: 429); more to the point, "languages differ enormously in the concepts that they provide ready-coded in grammar and lexicon” (Ibid.: 435) ${ }^{24}$. The idea of conceptual universals would therefore require hard evidence.

What we have in mind here is not that there are basic spatial concepts, or semantic primitives, but that, as was demonstrated for colors by Berlin \& Kay (1969), there are probably some spatial configurations which are more often expressed by languages than others. This is what seems to indicate the study on adpositions by Levinson et al. $\left(2003^{25}\right)$, which investigates the question of spatial categories, trying to find out whether there are implicational hierarchies in this domain. They show that, in the languages of their sample, simple adpositions follow a hierarchy: while some spatial configurations (such as AT, IN, ON) are expressed by adpositions in most or all languages, others are rarely expressed by (simple) adpositions (such as SPIKED, HANGING OVER, DISTRIBUTED OVER). The result of their study is thus an implicational hierarchy with more or less basic spatial configurations (Ibid.: 510):

$$
\text { AT }<\text { IN }<\text { ON, UNDER }<\text { OVER, NEAR }<\text { ON-TOP }<\text { ATTACHED }<\text { INSIDE }<\text { SPIKED, }
$$

HANGING, DISTRIBUTED OVER

This hierarchy is to be interpreted as follows: if there is a simple adposition for ON-TOP, there will be simple adpositions for all configurations to the left (i.e. AT, IN, ON, UNDER, OVER, NEAR). In other words, simple adpositions tend to refer to simple spatial configurations, more specifically topological relations, ${ }^{26}$ while more complex adpositions tend to encode intrinsic and relative relations; this phenomenon is widely attested, in languages which are typologically and geographically far apart (Fortis \& Fagard 2010: IV). This can be illustrated

\footnotetext{
${ }^{23}$ Of course, it is quite impossible to know what concepts underlie these adpositions. This is why we prefer to work with spatial configurations.

${ }^{24}$ The authors argue against two opposite claims - that "closed-class items reveal a recurrent set of semantic distinctions" (Talmy 2000) or that "open-class items (like nouns) are (...) less cross-linguistically variable” (Gentner \& Boroditsky 2001) -, considering that "neither of these views seems correct, for both ends of the spectrum are cross-linguistically variable” (Evans \& Levinson 2009: 436).

${ }^{25}$ Using a booklet of drawings illustrating various topological relations (spatial relations corresponding to those expressed by English in, on, under, over, near, against, inside, on top of, in the middle of...), Levinson et al. analyse the way adpositions are used in different languages to express topological relations. Their survey includes Basque, Dutch, Ewe, Lao, Lavukaleve, Tiriyó, Trumai, Yélî Dnye and Yukatek.

${ }^{26}$ Generic adpositions - such as simple adpositions in languages which have only one such adposition - are quite different, as we saw.
} 
with the opposition between adpositions used for topological configurations (e.g. coincidence, enclosure, cf. Herskovits 1986: 55) and others: in Romance languages, complex adpositions and adpositional phrases are indeed used for specific spatial configurations, while simple spatial adpositions have a wider range of uses; some spatial configurations, such as far from, all the way to, are never expressed by simple adpositions (Fagard 2010: 271, 284).

\subsection{The case of Romance}

We thus decided to adopt an onomasiological approach in order to check the validity of our hypothesis. We tried to find out how Romance languages use simple and complex adpositions for the spatial configurations illustrated above (Figures a-h). If French is more grammaticalized than other Romance languages, we would expect it to use simple adpositions more systematically for these semantic relations (cf. Sections 2, 3 and 5.1).

The matter should be quickly resolved, then: all one needs to do is find the adposition used, in each language, for each of those spatial configurations. However, it is no simple matter to identify the default construction used to express a given meaning, for various reasons. There are frequently various possible means of expression; there is often an opposition between a very frequent simple adposition which rarely has a spatial meaning (see Section 5.1: a higher degree of grammaticalization is linked to a greater semantic bleaching, and thus to fewer spatial uses), and a much less frequent complex adposition which is more systematically spatial. Levinson et al. "abstracted away from these additional codings" (ibid: 488), but we think it is essential to take them into account. Of course, there remains the question of which one is most natural; we tried to find this out on the basis of written and spoken corpora, which are listed in the reference section.

We met quite a few problems on the way. Thus, though Portuguese sob appears with a spatial meaning in written texts (11a), this meaning is quite rare in spoken Portuguese (11b - even there, a somewhat lexicalized example), where abstract uses are much more common (11c). Actually, even spatial situations give rise to abstract interpretations with such adpositions (11d).

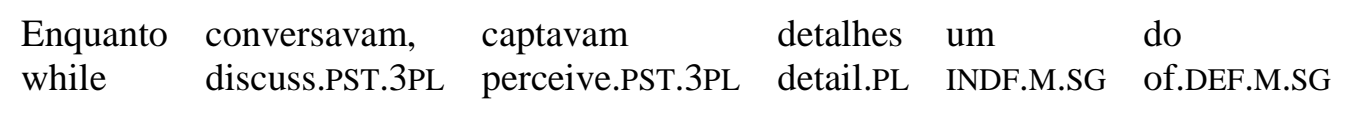

$$
\begin{aligned}
& \text { outro; sob a mesa pequena, os joelhos se } \\
& \text { other.M.SG under DEF.F.SG table.SG small.F.SG DEF.M.ML knee.PL REFL.3 }
\end{aligned}
$$

esbarravam ocasionalmente. meet.PST.3PL occasionally

'While they were talking, they perceived details one of the other; under the small table, their knees sometimes met.' (CdP, 19:Fic:Br:Garcia:Silencio)

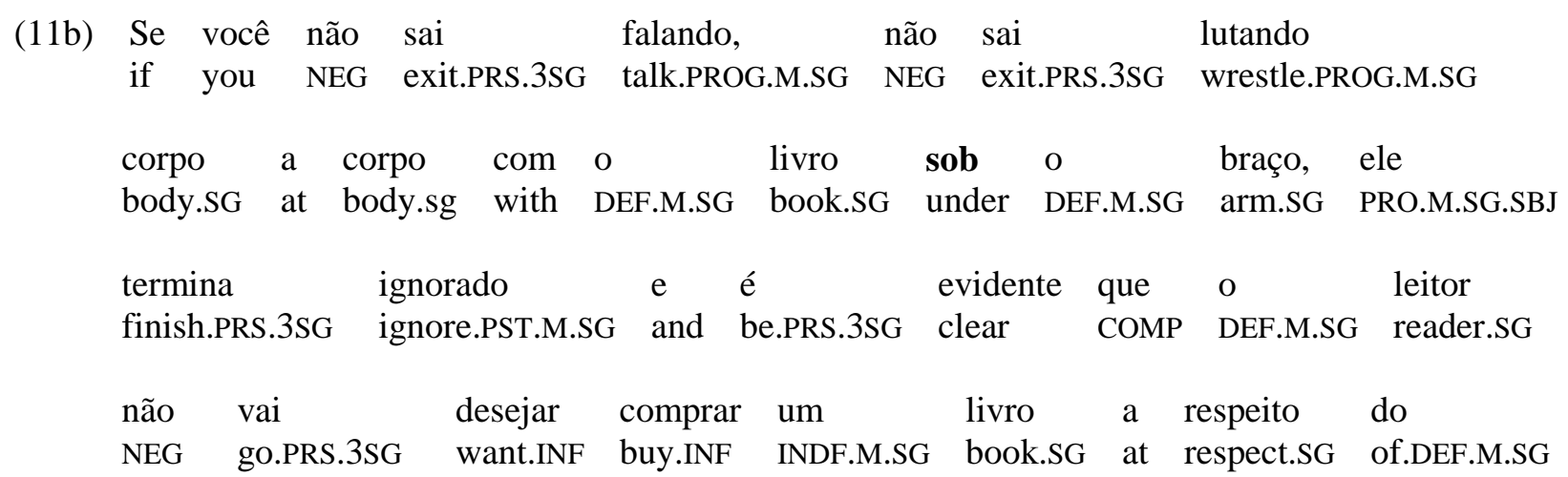


qual nunca ouviu falar.

which.M.SG never hear.PST.3sG talk.INF

'If you don't go and talk, wrestling bodily with your book under the arm, he ends up forgotten and clearly no reader will want to buy a book he never hear anyone talk about.' (CdP, 19Or:Br:Intrv:ISP)

(11c) Sempre pensei que teria de tomar esta opção, sob always think.PST.1SG COMP hold.COND.3SG of take.INF DEM.F.SG option.SG under

o risco de cair em situações desagradáveis.

DEF.M.SG risk.SG of fall.INF in situation.PL disagreeable.PL

'I always thought I would have to take this option, or risk falling into disagreeable situations.' (CdP, 19Or:Pt:Intrv:Jrnl)

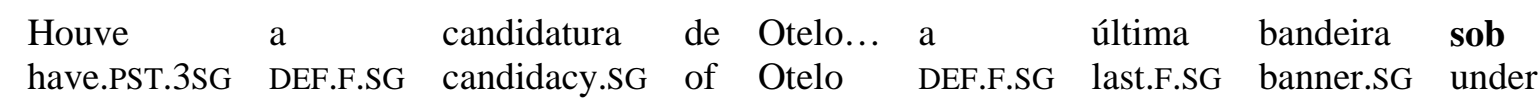
$\begin{array}{lllllll}\text { a } & \text { qual } & \text { se } & \text { acolheu } & \text { a } & \text { ultima (sic) } & \text { unidade... } \\ \text { DEF.F.SG } & \text { which.SG } & \text { REFL.3SG } & \text { receive.PST.3SG } & \text { DEF.F.SG } & \text { last.SG } & \text { unity.SG }\end{array}$ 'Otello was a candidate - the last banner under which we formed a unified front...' (CdP, 19Or:Pt:Intrv:Web)

The same can be said of Spanish ante, though the difference with delante de is less obvious: ante las cámaras seems to be associated with the meaning 'on TV' (12a), and delante de las cámaras with 'in front of the cameras' (12b). The association of simple adpositions with abstract meanings even in (potentially) spatial contexts is also perceptible for tras (12c).

(12a) A partir de hoy y todos los jueves, cuando el at leave.INF of today and ALL.M.PL DEF.M.PL Thursday.PL when DEF.M.SG

$\begin{array}{lllllll}\text { programa } & \text { debate } & \text { termine } & \text { ante } & \text { las } & \text { cámaras de } \\ \text { programm.SG } & \text { debate.SG } & \text { finish.PRS.3SG } & \text { in.front.of } & \text { DEF.F.PL } & \text { camera.PL } & \text { of }\end{array}$

televisión, después de la hora y media que saben television.SG after of DEF.F.SG hour.SG and half.F.SG REL know.PRS.3PL

$\begin{array}{lllllll}\text { ustedes } & \text { que } & \text { dura, } & \text { se } & \text { em } & \text { inaugurará } & \text { se } \\ \text { PRO.formal.2PL } & \text { COMP } & \text { last.PRS.3SG } & \text { REFL.3 } & \text { be(gin) } & \text { inaugurate.FUT.3SG } & \text { REFL.3 }\end{array}$

empezará celebraremos un coloquio que se emitirá

begin.FUT.3SG hold.FUT.1PL INDF.M.SG debate REL REFL.3 emit.FUT.3SG

por Radio Cadena.

through Radio Chain

'Starting today, on Thursdays, when the debates on TV are finished, after an hour and a half, as you know this is how long it lasts, there will be a discussion emitted on Radio Cadena.'

(Crea, 05/02/87, TVE 1, España)

(12b)

$\begin{array}{lllllll}\text { - Debes } & \text { estar } & \text { como } & \text { un } & \text { flan, } & \text { digo, } & \text { nerviosa. } \\ \text { must.PRS.2SG } & \text { be.INF } & \text { like } & \text { INDF.M.SG } & \text { pudding.SG } & \text { say.PRS.1SG } & \text { nervous.F.SG }\end{array}$ 


\begin{tabular}{|c|c|c|c|c|c|c|c|}
\hline $\begin{array}{l}\text { - No. } \\
\text { NEG }\end{array}$ & $\begin{array}{l}\text { Bueno, } \\
\text { good }\end{array}$ & $\begin{array}{l}\text { un } \\
\text { INDF.M.SG }\end{array}$ & $\begin{array}{l}\text { poquito. } \\
\text { bit.M.SG }\end{array}$ & $\begin{array}{ll}\text { Después } & \text { de } \\
\text { after } & \text { of }\end{array}$ & $\begin{array}{l}\text { tanto } \\
\text { so.much.M.SG }\end{array}$ & $\begin{array}{l}\text { tiempo, } \\
\text { time.SG }\end{array}$ & $\begin{array}{l}\text { siempre, } \\
\text { always }\end{array}$ \\
\hline $\begin{array}{l}\text { pero } \\
\text { but }\end{array}$ & $\begin{array}{l}\text { nada, } \\
\text { nothing }\end{array}$ & $\begin{array}{l}\text { cuar } \\
\text { as.m }\end{array}$ & $\begin{array}{l}\text { to } \\
\text { uch.M.SG }\end{array}$ & $\begin{array}{l}\text { hable } \\
\text { talk.PRS.SBJV.1SG }\end{array}$ & $\begin{array}{l}\text { contigo } \\
\text { with.PRO.2SG }\end{array}$ & $\begin{array}{l}\text { dos } \\
\text { two }\end{array}$ & $\begin{array}{l}\text { minutos } \\
\text { minute.PL }\end{array}$ \\
\hline $\begin{array}{l}\text { ya } \\
\text { already }\end{array}$ & $\begin{array}{l}\text { se } \\
\text { REFL.3 }\end{array}$ & $\begin{array}{l}\text { me } \\
\text { REFL.1SG }\end{array}$ & $\begin{array}{l}\text { pasa. } \\
\text { pass.PRS }\end{array}$ & & & & \\
\hline
\end{tabular}

$\begin{array}{lllllllll}\text { - Ponerse } & \text { delante } & \text { de } & \text { las } & \text { cámaras, } & \text { de } & \text { los } & \text { focos, } & \text { de } \\ \text { put.INF.REFL.3 } & \text { in.front } & \text { of } & \text { DEF.F.PL } & \text { camera.PL } & \text { of } & \text { DEF.M.PL } & \text { projector.M.PL } & \text { of }\end{array}$

pronto, después de tanto tiempo

quick.M.SG after of so.much.M.SG time

- Sí, pero te olvidas.

yes but REFL.2SG forget.PRS.2SG

- Sí, sí.

yes yes

'- You must feel real uncomfortable, I mean, nervous.

- No. Well, a little bit. After so much time, always, but no, just talking to you for two minutes and I feel fine.

- To find yourself in front of the cameras, of the projectors, after so much time...

- Yes, but you forget.

- Yeah.' (Crea, Barcelona, 06/03/91, TVE 1, España)

(12c) Guerrero, que ha estado gobernado por una estirpe de Guerrero REL have.PRS.3SG be.PST.M.SG govern.PST.M.SG by INDF.F.SG stock.SG of caciques asesinos y corruptos, y cuando no están ellos cacique.PL murderous.M.PL and corrupt.M.PL and when NEG be.3PL they.M.PL

dejan el poder tras el trono, $y$ siguen

leave.PRS.3PL DEF.M.SG power.SG behind DEF.M.SG throne.SG and continue.PRS.3PL

gobernando los caciques.

govern.PROG.M.SG DEF.M.PL cacique.PL

'[Take] Guerrero, which has been governed by a class of caciques, murderous and corrupt and when they do not govern themselves, they feign to leave the power and go on governing from behind the throne (i.e. the curtains).' (Crea, Cámara de Senadores de México)

Another problem arises with the distinction between simple and complex adpositions, which as we noted earlier is not always clear-cut. Thus, Portuguese fora de 'outside' is sometimes used as a simple adposition (13), though it then has an abstract meaning:

(13) As raves começaram a acontecer aqui depois de dois ou três DEF.F.PL rave.party.PL begin.PST.3PL at happen.INF here after of two or three

anos de acontecerem na $\quad$ Europa. Fora o $\quad$ eletrônico que

year.PL of happen.INF.3PL in.DEF.F.SG Europe outside DEF.M.SG electronic.SG REL 


$$
\begin{aligned}
& \text { não é } \quad \text { de } \text { pista } \quad-o \text { disco do } \quad \text { Agentss é } \\
& \text { NEG be.PRS.3SG of dance.floor.SG DEF.M.SG disc.SG of.DEF.M.SG Agentss be.PRS.3sG } \\
& \text { de } 81 \text { e nos anos } 80 \text { tinha até gravadora de } \\
& \text { of } 81 \text { and in.DEF.M.PL year.PL } 80 \text { have.PST.3SG including cutter of }
\end{aligned}
$$

Similarly, though it is possible to use davanti 'in front (of)' as a simple adposition (e.g. 243.000 occurrences of davanti la casa on the internet - Google search, 07/09/2010), the most frequent construction of davanti is as a transitivized adverb (859.000 occurrences of davanti alla casa, id.). In the Badip database, we found no occurrence of davanti used as a simple spatial adposition, but many occurrences as a transitivized adverb (as in è qui davanti “(s)he's (lit. here) in front”). Another example is Italian dietro, which seems less clearly adverbial, with almost one third of adpositional uses (of the type dietro la casa "behind the house"), as in (14b).

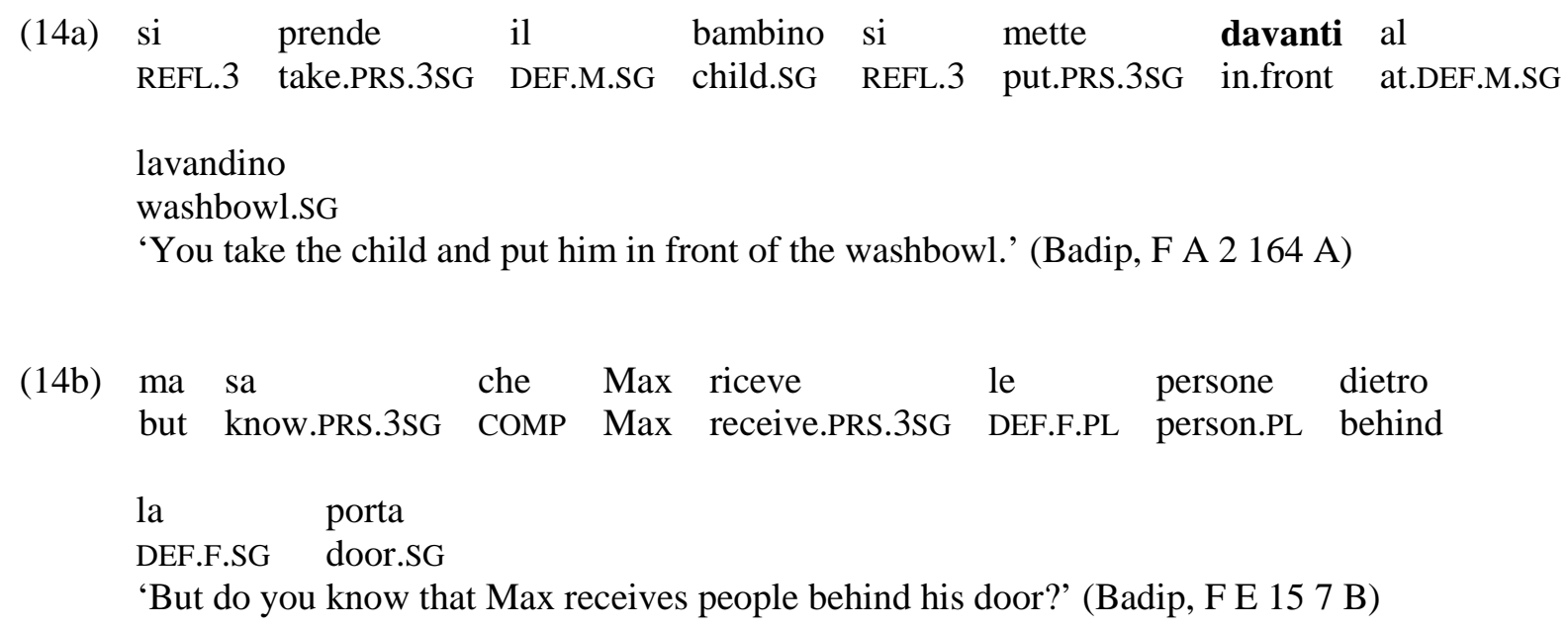

Some constructions are subject to little or no variation. These include complex adpositions with (very rare) uses as simple adpositions, as in Spanish (por) encima $+N$, corresponding to fewer than 10 occurrences in the whole Crea database (as in 15a), i.e. much rarer than (por) encima de $\mathrm{N}$ (more than 500 occurrences). The same can be said of dentro de (we found less than a dozen adpositional occurrences of dentro $\mathrm{N}, 4$ occurrences of por dentro de $\mathrm{N}$, but 3.000 occurrences of dentro de $\mathrm{N}$ ), as in (15b).

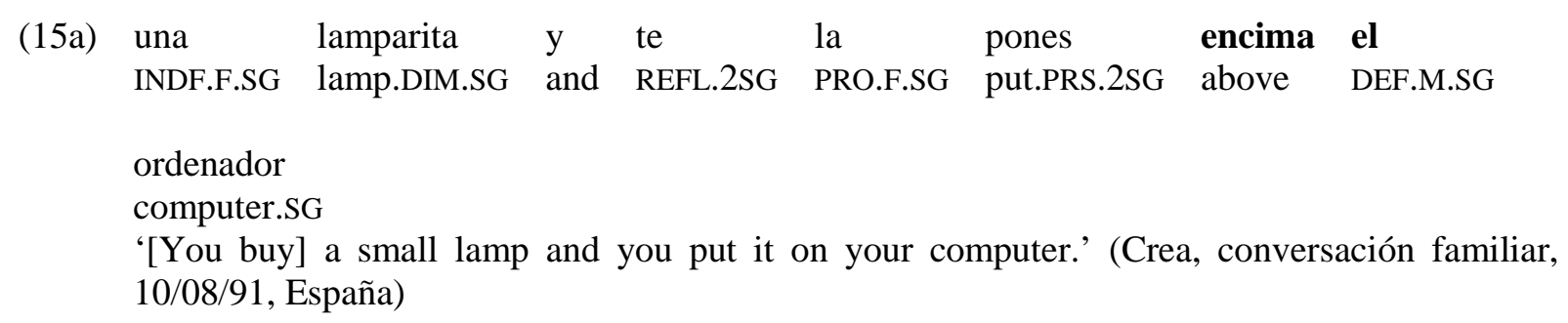


(15b)
Puede
$\begin{array}{lll}\text { que } & \text { pongas } & \text { el } \\ \text { COMP } & \text { put.PRS.SBJV.2SG } & \text { DEt }\end{array}$
el detalle de una
alfombra
can.PRS.3SG
detail.SG of
INDF.F.SG
rug.SG

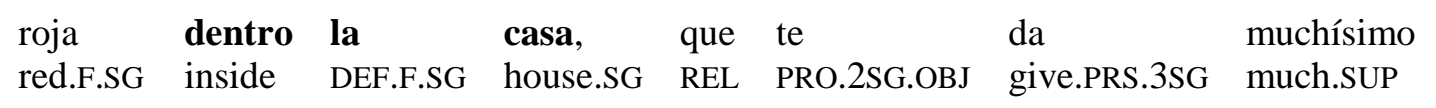

calor en un ambiente.

heat.SG in INDF.M.SG environment

'You could add the detail of a red rug in a house, and it adds a lot of warmth to your environment.' (Crea, LP4, Bolivia)

Another difficulty yet is that complex adpositions typically display a higher degree of morphological variation, which is often associated with semantic variation, such as French endessous and au-dessous 'below', between which the semantic distinction is delicate. This is particularly obvious in Portuguese, with the alternations em cima de / acima de / por cima de, which are associated to semantic variation, as in (16a-b), where em cima de clearly means 'on' (with contact) and acima do 'above' (without contact).

(16a) fui
fui
fazer uma
visita à
casa e encontrei
be.PST.1SG do.INF INDF.F.SG
visit.SG at.DEF.F.SG
house.SG and find.PST.1SG

$\begin{array}{llllllll}\text { um } & \text { monte } & \text { de } & \text { papéis } & \text { em } & \text { cima } & \text { do } & \text { sofá } \\ \text { INDF.M.SG } & \text { mountain.SG } & \text { of } & \text { paper.PL } & \text { in } & \text { top.SG } & \text { of.DEF.M.SG } & \text { sofa.SG }\end{array}$

cheio de poeira.

full.M.SG of dust.SG

'I went home to look around and found a huge pile of papers on top of the sofa, full of dust.'

(CdP, 19Or:Br:Intrv:ISP)

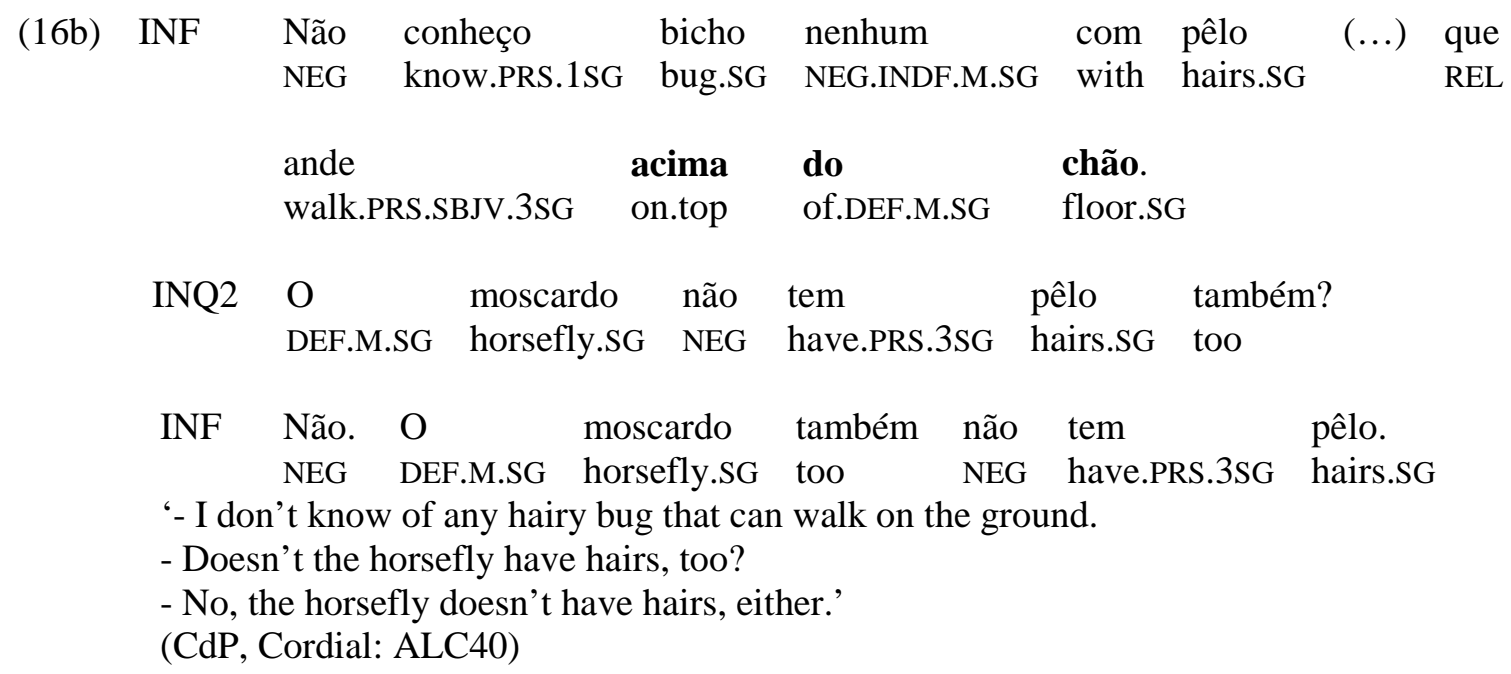

The examples above illustrate some of the difficulties we encountered. We tried to take into account all elements of semantic and morpho-syntactic variation in order to provide an adequate representation of the way Romance languages use adpositions to express these spatial configurations. We present in Tables 6-13 the results of our investigation, i.e. the default adposition or construction used to denote the corresponding configuration, along with less frequent or semantically marked adpositions, marked with a sharp sign (“\#”, here and in the following tables as well). 
First, all languages examined here have simple adpositions for IN, INSIDE, as shown in Table 6 , in which we indicate the relative frequency ${ }^{27}$ of all adpositions in spoken language corpora, based on the criteria illustrated by examples (11) to (16). This is expected, given the scale we presented above. The existence, next to these simple forms, of more precise and much less frequent complex adpositions is also expected.

\begin{tabular}{|l|c|c|c|c|c|}
\hline $\begin{array}{l}\text { Relative } \\
\text { frequency } \\
\text { (per million } \\
\text { words) }\end{array}$ & Spanish & French & Italian & Portuguese & Romanian \\
\hline$>2500$ & en & \#en, dans ${ }^{28}$ & in & em & în \\
\hline$>250$ & dentro de & & dentro & dentro de & \\
\hline$<50$ & $\begin{array}{c}\text { \#al (/ hacia el / } \\
\text { en el / por el...) } \\
\text { interior de }\end{array}$ & $\begin{array}{c}\text { \#à l'intérieur } \\
\text { de, "dedans }\end{array}$ & \#dentro a/di & $\begin{array}{c}\text { \#por dentro } \\
\text { de, \#para } \\
\text { dentro de }\end{array}$ & $\begin{array}{c}\text { \#̂̂n interiorul } \\
+G \text {, \#̂̂n sânul } \\
+G, \text { din sânul } \\
+G\end{array}$ \\
\hline
\end{tabular}

Table 6: Romance adpositions denoting the spatial configuration IN / INSIDE.

The same can be said of the spatial configuration of support: all languages have simple adpositions for ON, as shown in Table 7, but Ibero-Romance stands apart, with an adposition that is underspecified for inclusion and support (with contact). These adpositions are specifically used to express spatial configurations involving contact; as we will see below, situations where there is no contact are generally expressed by complex adpositions.

\begin{tabular}{|l|c|c|c|c|c|}
\hline $\begin{array}{l}\text { Relative } \\
\text { frequency } \\
\text { (per million } \\
\text { words) }\end{array}$ & Spanish & French & Italian & Portuguese & Romanian \\
\hline$>5000$ & en & & & em & pe \\
\hline$>1000$ & sobre & sur & su & sobre & \\
\hline
\end{tabular}

Table 7: Romance adpositions denoting the spatial configuration ON.

The case of UNDER is slightly different: although all languages have simple adpositions, it seems that at least Portuguese baixo and Spanish bajo rather take on abstract uses, which is not necessarily the case of the other simple adpositions listed in Table 8. Relative frequencies indicate a specialization of French sous and Romanian sub, with complex adpositions clearly much less frequent.

\begin{tabular}{|l|c|c|c|c|c|}
\hline $\begin{array}{l}\text { Relative } \\
\text { frequency (per } \\
\text { million words) }\end{array}$ & Spanish & French & Italian & Portuguese & Romanian \\
\hline$>100$ & bajo & sous & sotto & sob & sub \\
\hline$>20$ & debajo de & & sotto a & $\begin{array}{c}\text { debaixo de, abaixo } \\
\text { de }\end{array}$ & \\
\hline$>15$ & & $\begin{array}{c}\text { al di sotto } \\
\text { di }\end{array}$ & & \\
\hline
\end{tabular}

${ }^{27}$ Relative frequencies are computed on the basis of, on the one hand, automatic counts of adpositions in spoken language corpora and, on the other hand, a hand-count of the proportion of non-ambiguous spatial uses, on an abritary selection, for each adposition. The threshholds indicated vary with the frequencies of each group of adpositions. The corpora are listed in the reference section.

${ }^{28}$ Though the adposition en can be used with a spatial meaning, its most frequent uses are rather abstract (see De Mulder 2008: 284 and De Mulder \& Amiot, unpublished manuscript). 


\begin{tabular}{|l|l|c|l|l|l|}
\hline$<10$ & por debajo de & $\begin{array}{c}\text { en-dessous } \\
\text { de, au- } \\
\text { dessous de, } \\
\text { dessous }\end{array}$ & al di sotto & $\begin{array}{c}\text { em baixo de, por } \\
\text { debaixo de }\end{array}$ & $\begin{array}{c}\text { dedesubt, } \\
\text { dedesubtul }\end{array}$ \\
\hline
\end{tabular}

Table 8: Romance adpositions denoting the spatial configuration BELOW.

For AMONG / BETWEEN, Romance languages all have simple adpositions; as illustrated in Table 9, they also use complex adpositions, though their frequency is much lower. Relative frequencies show a greater specialization in French, with a greater difference between entre and the other options for expressing loose insertion.

\begin{tabular}{|l|c|c|c|c|c|}
\hline $\begin{array}{l}\text { Relative } \\
\text { frequency } \\
\text { (per million } \\
\text { words) }\end{array}$ & Spanish & French & Italian & Portuguese & Romanian \\
\hline$>500$ & entre & entre & tra, fra & entre & între \\
\hline$>100$ & dentro de & & & no meio de & printre \\
\hline$<50$ & $\begin{array}{c}\text { parmi, au } \\
\text { sein de }\end{array}$ & in mezzo a & dentre & $\begin{array}{c}\text { în sânul, din } \\
\text { sânul }\end{array}$ \\
\hline$<10$ & $\begin{array}{c}\text { por entre, por } \\
\text { dentro (de) }\end{array}$ & & nel mezzo di & & \\
\hline
\end{tabular}

Table 9: Romance adpositions denoting the spatial configuration AMONG / BETWEEN.

All other spatial configurations examined here automatically trigger the use of complex adpositions in one or more languages. Thus, IN FRONT OF is expressed by complex adpositions in Romanian and Italian, as illustrated in Table 10. Besides, Spanish ante and Portuguese perante tend to be associated with abstract meanings, so that the default spatial forms are rather delante de and diante de, respectively.

\begin{tabular}{|l|c|c|c|c|c|}
\hline $\begin{array}{l}\text { Relative } \\
\text { frequency (per } \\
\text { million } \\
\text { words) }\end{array}$ & Spanish & French & Italian & Portuguese & Romanian \\
\hline$>100$ & \#ante & devant & $\begin{array}{c}\text { davanti a, } \\
\text { \#davanti }\end{array}$ & $\begin{array}{c}\text { diante de, } \\
\text { \#perante }\end{array}$ & în faţa $+\mathrm{G}$ \\
\hline$>50$ & delante de & & \#di fronte a & $\begin{array}{c}\text { \# em frente } \\
\text { (de/a) }\end{array}$ & \\
\hline$>10$ & & \# en face (de) & & \#defronte de & \\
\hline$<10$ & \#por delante de & en face & & $\begin{array}{c}\text { în fruntea }+\mathrm{G}, \\
\text { înaintea }+\mathrm{G}, \text { în } \\
\text { capul }+\mathrm{G}\end{array}$ \\
\hline
\end{tabular}

Table 10: Romance adpositions denoting the spatial configuration IN FRONT OF.

Note that these adpositions are not exactly equivalent, among other things because the importance of the intrinsic orientation of the complement is variable, as illustrated by the spatial configurations below (Vandeloise 1991: 97-98). According to Vandeloise, it is possible to say le râteau est devant le crabe 'the rake is in front of the crab' only in Figure i, while in Figure j devant le crabe would have to apply to the net (le filet est devant le crabe); however, en face de would have to apply to the net in both figures. 


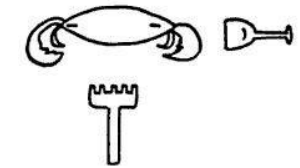

Figure i

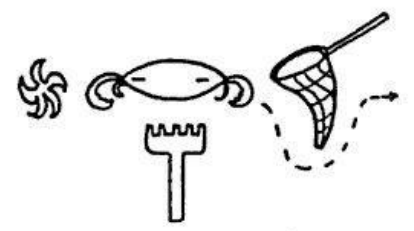

Figure j

The spatial configuration BEHIND is also expressed by complex adpositions in some of these languages: Spanish, Portuguese and Romanian, as illustrated in Table 11, without the variation noted for IN FRONT OF. The case of Spanish is particularly interesting, given that Medieval Spanish had a simple adposition (tras) with this meaning (Fagard 2010: 249), and now uses it as a complex adposition in the construction (por) detrás de. French is the only language with a frequent simple adposition and no variation ${ }^{29}$.

\begin{tabular}{|c|c|c|c|c|c|}
\hline $\begin{array}{l}\text { Relative } \\
\text { frequency (per } \\
\text { million words) }\end{array}$ & Spanish & French & Italian & Portuguese & Romanian \\
\hline$>50$ & detrás de & derrière & dietro & atrás de & \\
\hline$>10$ & & & ${ }^{\#}$ dietro a & $\begin{array}{c}\text { \#detrás de, " por } \\
\text { detrás de }\end{array}$ & \\
\hline$<5$ & \#por detrás de & & $\begin{array}{c}{ }^{\#} \text { al di dietro } \\
\text { di }\end{array}$ & \#para detrás de & $\begin{array}{l}\text { în spatele }+G \text {, } \\
\text { înapoia }+G \text {, } \\
\text { îndărătul }+G\end{array}$ \\
\hline
\end{tabular}

Table 11: Romance adpositions denoting the spatial configuration BEHIND.

The spatial configuration ABOVE is expressed by complex adpositions everywhere; only French, Italian and Spanish use both simple and complex forms, as illustrated in Table 12. Note that in Italian, the default form is simple (sopra), while in Spanish and French the default form is complex (encima de, au-dessus de). The high relative frequency of adpositions based on cima in Spanish and Portuguese is linked to their use as indicative of support with contact. $^{30}$

\begin{tabular}{|l|c|c|c|c|c|}
\hline $\begin{array}{l}\text { Relative } \\
\text { frequency (per } \\
\text { million } \\
\text { words) }\end{array}$ & Spanish & French & Italian & Portuguese & Romanian \\
\hline$>100$ & " encima & & & & \\
\hline$>50$ & encima de & & & $\begin{array}{c}\text { acima de, } \\
\text { em cima de }\end{array}$ & \\
\hline$>10$ & "por encima de & au-dessus de & & por cima de & asupra $+\mathrm{G}$ \\
\hline$<5$ & \#au-dessus & $\begin{array}{c}\text { sopra, }{ }^{\#} \text { sopra } \\
\text { al di sopra } \\
\text { di }\end{array}$ & em sobre & deasupra $+\mathrm{G}$ \\
\hline
\end{tabular}

Table 12: Romance adpositions denoting the spatial configuration ABOVE.

Finally, the spatial configuration OUTSIDE is typically expressed by complex adpositions in all languages, as illustrated in Table 13: although some simple forms exist (French hors, Italian fuori, Portuguese fora), they all have very marked uses, occurring only in fixed constructions

\footnotetext{
${ }^{29}$ As far as grammaticalized expressions are concerned. Of course, French also has lexical means of expressing this semantic relation, such as dans le dos de, lit. "in the back of".

${ }^{30}$ We did not exclude these uses, because it is not easy to disambiguate them without extralinguistic context.
} 
such as Italian fuori città 'out of town', fuori le mura 'beyond the city walls', fuori Roma 'outside of Rome', and have low relative frequencies.

\begin{tabular}{|c|c|c|c|c|c|}
\hline $\begin{array}{l}\text { Relative } \\
\text { frequency } \\
\text { (per million } \\
\text { words) }\end{array}$ & Spanish & French & Italian & Portuguese & Romanian \\
\hline$>50$ & fuera de & & $\begin{array}{c}\text { fuori di, }{ }^{\#} \text { fuori } \\
\text { da }\end{array}$ & fora de & în afara $+G$ \\
\hline$>10$ & & $\begin{array}{l}\text { hors de, en- } \\
\text { dehors de }\end{array}$ & ${ }^{*}$ fuori & & \\
\hline$<5$ & $\begin{array}{l}{ }^{\#} \text { por fuera de, }{ }^{\#} \text { al } \\
\text { exterior de }\end{array}$ & ${ }^{\text {"hors }}$ & $\begin{array}{l}\text { "all'infuori di, } \\
\text { al di fuori di }\end{array}$ & ${ }^{\#}$ fora & în exteriorul +G \\
\hline
\end{tabular}

Table 13: Romance adpositions denoting the spatial configuration OUTSIDE.

\subsection{Discussion}

This brief description seems to confirm - at least in the five languages we examined - the existence of spatial configurations of different types, some basic, others less so. There are first 'basic' spatial configurations such as inclusion and support. ${ }^{31}$ There are also various types of more complex spatial configurations, including projective configurations (in front of, behind) or configurations associated with more than one semantic feature (ABOVE being associated for instance with both superiority on the vertical axis and absence of contact). These configurations may be expressed by simple adpositions, but are consistently expressed by complex adpositions. A gradient of grammaticalization can be elaborated on the basis of how many of these configurations a language expresses with simple adpositions. From this point of view, French seems indeed to be the most grammaticalized, followed by Italian, Spanish, Portuguese and Romanian, in that order.

\section{Conclusion}

After a brief look at the framework of grammaticalization theory and at Latin adpositional paradigms, we tried to describe the uses of adpositions in Romance, from two points of view which we consider complementary. In all Romance languages examined here, the systems of adpositions result from the grammaticalization of various (mostly noun-based) constructions, lexical items and already grammaticalized adpositions - all three processes being instances of grammaticalization, and involving the same basic phenomena, but with different results: complex adpositions, simple adpositions and 'functional' adpositions.

The grammaticalization of new simple adpositions (on the basis of participles, adverbs or nouns) is found in all Romance languages, as well as that of adpositions into functional adpositions; these adpositions are mostly grammaticalized on the basis of one Latin adposition, with a few exceptions: Romanian la < illac ad, Italian $d a<d e$ ad. Finally, patterns of complex adpositions are also found in all Romance languages. We showed that French grammaticalized further its renewed stock, creating more simple adpositions than the other languages and more rigid patterns of complex adpositions, followed by Italian, then Spanish, Portuguese and Romanian.

\footnotetext{
${ }^{31}$ As well as the relation of contact, which we did not investigate but is sometimes expressed by functional adpositions (à, $a$, la “at”), in all Romance languages. For this adposition, too, it seems that French displays more grammaticalized uses than other Romance languages; see Goyens, Lamiroy \& Melis (2002: 302).
} 
We then confirmed this trend on the basis of an onomasiological study, comparing our data with spoken databases in order to make sure that they reflected actual language use. This approach yielded similar results, and thus seems to confirm the observations already made on the basis of other parts of the language: as far as adpositions are concerned, if our approach is valid, French is indeed the most grammaticalized Romance language, followed by Italian, Spanish, Portuguese and Romanian. Many questions remain; for instance, does our hypothesis remain valid for other domains than space? Are spatial configurations really representative?

\section{References}

Abeillé, Anne, Danièle Godard, Olivier Bonami \& Jesse Tseng. 2003. The syntax of French à and de: an HPSG analysis. In Patrick Saint-Dizier (ed.), Syntax and the semantics of prepositions. Dordrecht: Kluwer, 133-144.

Aikhenvald, Alexandra Y. 2004. Evidentiality. Oxford: Oxford University Press.

Berlin, Brent \& Paul Kay. 1969. Basic color terms: their universality and evolution. Berkeley / Los Angeles: University of California Press.

Brøndal, Viggo. 1939. L'originalité des prépositions du français moderne. In Albert Sechehaye et al. (eds.), Mélanges de linguistique offerts à Charles Bally. Genève: Georg et cie, 337-346.

Brown, Penelope. 2006. A sketch of the grammar of space in Tzeltal. In Stephen Levinson \& David Wilkins (eds.), Grammars of space. Cambridge: Cambridge University Press, 230-72.

Bybee, Joan \& Paul Hopper (eds.). 2001. Frequency and the emergence of linguistic structure, Amsterdam / Philadelphia: John Benjamins.

Bybee, Joan. 2006. From usage to grammar: The mind's response to repetition. Language 82/4, 711733.

Carlier, Anne. 2007. From Preposition to Article. The grammaticalization of the French partitive. Studies in Language, 31, 1, 1-49.

Ciobanu, Fulvia \& Isabela Nedelcu. 2008. Prepoziţia. In Valeria Guţu Romalo (coord.), Gramatica limbii române. Vol. 1, Cuvântul. București: Editura Academiei Române, 607-630.

Company Company, Concepción. 2002. Grammaticalization and category weakness. In Ilse Wischer \& Gabriele Diewald (eds.), New Reflections on Grammaticalization. Amsterdam / Philadelphia: John Benjamins, 201-215.

Cuniță, Alexandra. 2004. Prepoziţia, abordări vechi şi noi în lingvistica românească. In Gabriela Pană Dindelegan (ed.), Tradiţie şi inovaţie în studiul limbii române. Bucureşti: Editura Universităţii din Bucureşti, 79-85.

De Mulder, Walter \& Lamiroy Béatrice. To appear. Stages of Grammaticalization: the position of French among the other Romance languages. In Bert Cornillie \& Hubert Cuyckens (eds.), New Reflections on Grammaticalization. Amsterdam / Philadelphia: John Benjamins.

De Mulder, Walter. 2001. La Linguistique Diachronique: grammaticalisation et sémantique du prototype. Langages 130, 8-32.

De Mulder, Walter. 2008. En et dans : une question de « déplacement» ? In Olivier Bertrand, Sophie Prévost, Michel Charolles, Jacques François \& Catherine Schnedecker (eds.), Discours, diachronie, stylistique du français - Etudes en hommage à Bernard Combettes. Bern: Peter Lang, 277-291.

De Mulder, Walter \& Dany Amiot, Unpublished manuscript. L’insoutenable légèreté de la préposition en.

De Mulder, Walter \& Anne Vanderheyden. 2000. Vers une sémantique diachronique cognitive? Réflexions sur l'évolution de la préposition sur. In Annick Englebert, Michel Pierrard, Laurence Rosier \& Dan Van Raemdonck (eds.), Actes du XXIIe Congrès International de Linguistique et de Philologie Romanes, vol. II. Tübingen: Max Niemeyer, 129-238.

DeLancey, Scott. 2005. Adpositions as a non-universal category. In Zygmunt Frajzyngier, Adam Hodges \& David Rood (eds.), Linguistic diversity and language theories. Amsterdam: John Benjamins, 185-202.

Di Meola, Claudio. 2000. Die Grammatikalisierung deutscher Präpositionen. Tübingen: Stauffenburg.

Evans, Nicholas \& Stephen C. Levinson. 2009. The myth of language universals: Language diversity and its importance for cognitive science. Behavioral and Brain Sciences 32, 429-492. 
Fagard, Benjamin. 2006. La grammaticalisation en question - du latin aux langues romanes modernes, Modèles linguistiques XXVII-1/53, 91-110.

Fagard, Benjamin. 2010. Espace et grammaticalisation: l'évolution sémantique des prépositions dans les langues romanes. Sarrebrück: Editions Universitaires Européennes.

Fagard, Benjamin \& Alexandru Mardale. 2007. Systèmes prépositionnels des langues romanes: la notion de partie du discours en diachronie. In David Trotter (ed.), Actes du XXIVème Congrès International de Linguistique et Philologie Romanes, Vol. 1. Tübingen: Niemeyer, 91-105.

Fortis, Jean-Michel \& Benjamin Fagard. 2010. Space in Language. Leipzig Summer School of Typology, August 14-28, 2010. Available on-line: http://htl.linguist.univ-parisdiderot.fr/jmfortis.htm.

Gaatone, David. 2001. Les prépositions : une classe aux contours flous, Travaux de linguistique 42/43, 23-31.

Gawełko, Marek. 1999. Classification des langues romanes et pouvoir explicatif des critères. Zeitschrift für romanische Philologie 115, 20-44.

Gawełko, Marek. 2001. Sobre la tendencia analítica de algunas lenguas romances: español, italiano y portugués. Revista española de lingüística, 31 (2), 393-412.

Gentner, Dedre \& Lera Boroditsky. 2001. Individuation, relational relativity and early word learning. In Melissa Bowerman \& Stephen Levinson (eds.), Language acquisition and conceptual development. Cambridge: Cambridge University Press, 215-256.

Goyens, Michèle, Béatrice Lamiroy \& Ludo Melis. 2002. Déplacement et repositionnement de la préposition à en français. Lingvisticae Investigationes 25(2), 275-310.

Grinevald, Colette. 2006. The expression of static location in a typological perspective. In Maya Hickmann \& Stéphane Robert (ed.), Space in languages: linguistic systems and cognitive categories. Amsterdam / Philadelphia: John Benjamins, 29-58.

Hagège, Claude. 2010. Adpositions. Oxford: Oxford University Press.

Hallan, Naomi. 2001. Paths to prepositions? A Corpus-Based Study of the Acquisition of a LexicoGrammatical Category. In Joan L. Bybee \& Paul Hopper (eds.), Frequency and the emergence of linguistic structure, Amsterdam / Philadelphia: John Benjamins, 91-120.

Haverling, Gerd. 2003. On prefixes and actionality in classical and late Latin, Acta linguistica Hungarica 50(1-2). Kiefer, Ferenc \& Wolfgang Dressler (eds.), Budapest: Akedémiai kiadó, 113135.

Hickmann, Maya. 2007. Static and dynamic location in French: Developmental and cross-linguistic perspectives. In Michel Aurnague, Maya Hickmann \& Laure Vieu (eds.), The categorization of spatial entities in language and cognition. Amsterdam: John Benjamins, 205-231.

Hopper, Paul \& Elizabeth Traugott. 2003 [1993]. Grammaticalization. Cambridge: Cambridge University Press.

Jakubowicz Batoréo, Hanna. 2000. Expressão do espaço no português europeu. Contributo psicolinguístico para o estudo da linguagem e cognição. Coimbra: Fundação Calouste Gulbenkian.

Johnston, Judith \& Dan Slobin. 1979. The development of locative expressions in English, Italian, Serbo-Croatian and Turkish. Journal of Child Language 6: 529-545.

König, Ekkehard \& Volker Gast. 2007. Understanding English-German Contrasts. Berlin: Schmidt.

Lamiroy, Béatrice. 1999. Auxiliaires, langues romanes et grammaticalisation. Langages, 135, 33-45.

Lamiroy, Béatrice. 2001. Le syntagme prépositionnel en français et en espagnol: une question de grammaticalisation ? Langages, 143, 91-106.

Lamiroy, Béatrice. 2003. The External Possession Structure and Grammaticalisation in Romance and Germanic languages. In: D’Hulst, Yves \& Martine Coene (eds.). From NP to DP. The expression of Possession in Noun Phrases (Vol. II). Amsterdam: John Benjamins, 257-281.

Lamiroy, Béatrice. 2011. Degrés de grammaticalisation à travers les langues de même famille. Bulletin de la Société de Linguistique de Paris 19, 167-192.

Lehmann, Christian. 1985. Grammaticalization: synchronic variation and diachronic change. Lingua e Stile 20(3): 303-318.

Lehmann, Christian. 1995. Thoughts on Grammaticalization. München, Newcastle: Lincom Europa.

Leumann, Manu, Johann Hofmann \& Anton Szantyr. 1965. Lateinische Grammatik. München: C. H. Beck. 
Levinson, Stephen, Sérgio Meira \& The Language and Cognition Group. 2003. 'Natural concepts ' in the spatial topological domain - adpositional meanings in crosslinguistic perspective: an exercise in cognitive typology. Language, 79(3): 485-516.

Marchello-Nizia, Christiane. 1995. L'évolution du français : ordre des mots, démonstratifs, accent tonique. Paris: A. Colin.

Marchello-Nizia, Christiane. 2006. Grammaticalisation et changement linguistique. Bruxelles: De Boeck-Duculot.

Mardale, Alexandru. 2009. Les prépositions fonctionnelles du roumain. Études comparatives sur le marquage casuel. Paris: L'Harmattan.

Meillet, Antoine. 1948. Linguistique historique et linguistique générale. Paris: Champion.

Melis, Ludo. 2003. La préposition en français. Gap / Paris: Ophrys.

Morgenstern, Aliyah \& Martine Sekali. 1997. L'acquisition des premières prépositions chez un enfant francophone. La préposition : une catégorie accessoire ? Faits de langues 9: 201-210.

Noonan, Michael. 2007. Complementation. In Timothy Shopen (ed.), Language Typology and Syntactic Description: Complex constructions. Cambridge: Cambridge University Press, 52-150.

Piaget, Jean \& Bärbel Inhelder. 1956 [1948]. The child's conception of space. London: Routledge / Kegan Paul.

Prévost, Sophie \& Benjamin Fagard. 2007. Présentation: Grammaticalisation et lexicalisation: la formation d'expressions complexes. Langue française 156: 3-8.

Rizzi, Luigi. 1988. Il sintagma preposizionale. In Lorenzo Renzi \& Giampaolo Salvi (eds.), Grande Grammatica di consultazione, Bologna: Il Mulino, 507-531.

Sausy, Lucien. 1992. Grammaire latine complète. $8^{\text {th }}$ ed. Paris: Fernand Lanore.

Schøsler, Lene. 2008. L'expression des traits manière et direction des verbes de mouvement. Perspectives diachroniques et typologiques. In Elisabeth Stark, Roland Schmidt-Riese \& Eva Stoll, (eds.). Romanische Syntax im Wandel. Tübingen: Gunter Narr, 113-132.

Svorou, Soteria. 1994. The grammar of space. Amsterdam / Philadelphia: John Benjamins.

Talmy, Leonard. 1972. Semantic Structures in English and Atsugewi. Dissertation, University of California, Berkeley.

Talmy, Leonard. 2000. Toward a Cognitive Semantics, vol. 1 \& 2. Cambridge: MIT Press.

Vandeloise, Claude. 1991. Spatial prepositions: a case study from French. Chicago: University of Chicago Press.

Van Riemsdijk, Henk. 1990. Functional Prepositions. In Harm Pinkster \& Inge Genee (eds.), Unity in diversity, Dordrecht: Foris, 229-241.

Wierzbicka, Anna. 1988. The Semantics of Grammar. Amsterdam / Philadelphia: John Benjamins.

Zwarts, Joost. 1997. Lexical and Functional Properties of Prepositions. In Dagmar Haumann \& Stefan Schierholz (eds.), Lexikalische und grammatische Eigenschaften präpositionaler Elemente. Tübingen: Max Niemeyer Verlag, 1-18.

\section{Corpora}

Romanian: Ruxăndoiu and CORV.

Portuguese: Corpus do Português, Davies, Mark and Michael Ferreira. (2006-) (45 million words, 1300s-1900s). Available online at http://www.corpusdoportugues.org.

Spanish: Crea (http://corpus.rae.es/creanet.html) and Corpus del español, Davies, Mark. (2002-) (100 million words, 1200s-1900s). Available online at http://www.corpusdelespanol.org.

Italian: Corpus Badip (http://badip.uni-graz.at/).

French: Clapi (http://clapi.univ-lyon2.fr/) and Valibel (http://www.uclouvain.be/valibel-corpus.html). 